\title{
Electrochemical and Photoelectrochemical Properties of Nano-Islands of Zinc and Niobium Oxides Deposited on Aluminum Thin Film by RF Magnetron Reactive Sputtering
}

\author{
Go Sajiki 1*, Yasuhiko Benino², Tokuro Nanba², Hiroshi Okano ${ }^{3}$ \\ ${ }^{1}$ Technological, Educational Supporting Center in Takamatsu, Kagawa National College of Technology, \\ Takamatsu, Japan \\ ${ }^{2}$ Graduate School of Environmental and Life Science, Okayama University, Okayama, Japan \\ ${ }^{3}$ General Education, Kagawa National College of Technology, Takamatsu, Japan \\ Email: sajiki@t.kagawa-nct.ac.jp
}

Received 17 February 2015; accepted 6 April 2015; published 8 April 2015

Copyright () 2015 by authors and Scientific Research Publishing Inc.

This work is licensed under the Creative Commons Attribution International License (CC BY). http://creativecommons.org/licenses/by/4.0/

(c) (i)

Open Access

\begin{abstract}
Zinc oxide ( $\mathrm{ZnO})$ and niobium oxide $\left(\mathrm{NbO}_{\mathrm{x}}\right)$ with a nano-island structure were deposited by a sputtering method on Al-coated glass substrates. Cells with a $\left(\mathrm{ZnO}\right.$ or $\left.\mathrm{NbO}_{\mathrm{x}}\right) / \mathrm{Al} / \mathrm{glass}\left|\mathrm{KNO}_{3} \mathrm{aq}.\right| \mathrm{Al} /$ glass structure were assembled, and electrochemical and photoelectrochemical properties were evaluated. The $\mathrm{ZnO}$ and $\mathrm{NbO}_{\mathrm{x}}$ electrodes had higher electrode potentials than the counter $\mathrm{Al} / \mathrm{glass}$ electrode, and electron flows from the counter electrode to the $\mathrm{ZnO}$ and $\mathrm{NbO}_{\mathrm{x}}$ electrodes through the external circuit were commonly confirmed. In the ZnO-based cell, only faint photocurrent generation was seen, where $\mathrm{Zn}$ and $\mathrm{Al}$ elution from the $\mathrm{ZnO}$ electrode was found. In the $\mathrm{NbO}_{\mathrm{x}^{-}}$ based cell, however, stable generation of electricity was successfully achieved, and electrode corrosion was not recognized even in microscopic observations. A photoelectrochemical conversion model was proposed based on potential-pH diagrams. In the case of nano-island structures formed at shorter $\mathrm{NbO}_{\mathrm{x}}$ deposition time, it was concluded that the photoelectrochemical reactions, which were proceeded in the immediate vicinity of the boundary among nano-islands, substrate, and electrolyte solution, were predominant for the photoelectrochemical conversion, and in the case of film structures with longer deposition time, the predominant reactions took place at the film surface.
\end{abstract}

"Corresponding author.

How to cite this paper: Sajiki, G., Benino, Y., Nanba, T. and Okano, H. (2015) Electrochemical and Photoelectrochemical Properties of Nano-Islands of Zinc and Niobium Oxides Deposited on Aluminum Thin Film by RF Magnetron Reactive Sputtering. Materials Sciences and Applications, 6, 292-309. http://dx.doi.org/10.4236/msa.2015.64035 


\section{Keywords}

\section{Nano-Island, Electrochemistry, Photoelectrochemistry, Niobium and Zinc Oxide, Corrosion}

\section{Introduction}

In recent years, various energy conversion devices, such as photovoltaic, thermoelectric, and piezoelectric devices, have been extensively studied because fossil fuel may run out within the next several decades. Among the devices, it is guessed that demand for the photovoltaic solar cells rises rapidly, because solar energy is semipermanent and is used anywhere under sunlight. However, there are various problems in solar cells, such as material cost, process cost, and power generation efficiency, and a number of attempts have been made to solve these problems [1]-[5]. Photoelectrochemical cells (PECs) have been also studied extensively [6]-[10], because they can produce not only electricity but also chemical energies such as hydrogen and oxygen by water splitting [11].

In the authors' research group [12], a laminated structure of $\mathrm{ZnO}$ (nano-islands)/Al (thin film)/glass was prepared, and it was found that Al thin film was etched in deionized water under UV irradiation by photocatalytic effect of $\mathrm{ZnO}$ nano-islands [12]. It was supposed that the Al-etching was due to an oxidation-reduction reaction, and hence if a cell had been formed, it should have been a solar cell. Then, in the present study, photoelectrochemical property of $\mathrm{ZnO}$ nano-islands was evaluated by using the $\mathrm{ZnO} / \mathrm{Al} /$ glass structure as a photovoltaic electrode. In the previous study [12], Al elution from the electrode was observed, which was not suitable for PEC, and the electrodes must be electrochemically stable. Then, electrochemical property was also investigated in the present study. On the other hand, it was reported that $\mathrm{Nb}_{2} \mathrm{O}_{5}$ had photocatalytic activity and showed higher deterioration resistance in photocatalytic activity than $\mathrm{ZnO}$ [13]. Hence, in the present study, $\mathrm{NbO}_{\mathrm{x}}$ nano-islands were also deposited on the $\mathrm{Al} /$ glass substrate for expecting higher corrosion and acid resistance than $\mathrm{ZnO}$, and electrochemical and photoelectrochemical properties were examined.

Anyway, PECs have not been put to practical use yet, because the conversion efficiency had been not enough. In order to improve the conversion efficiency, various nano-textures have been studied so far: for example in $\mathrm{ZnO}$ and $\mathrm{NbO}_{\mathrm{x}}$, nanotubes [14] [15], nanowires [16] [17], nanoparticles [18] [19], nanorods [20] [21] and so on [22]-[26]. To the best of the authors' knowledge, PECs with a nano-island structure have never been reported, where nano-islands are two-dimensionally and separately distributed on a substrate, and they are not in a stacking structure with nano-particles.

In the present study, not only nano-island but also continuous film structures of $\mathrm{NbO}_{\mathrm{x}}$ deposits were fabricated by changing deposition time to clarify the nano-texture dependence on the electrochemical and photoelectrochemical properties, in which surface states of $\mathrm{ZnO}$ and $\mathrm{NbO}_{\mathrm{x}} / \mathrm{Al} / \mathrm{glass}$ electrodes and $\mathrm{Al} / \mathrm{glass}$ substrate were observed by atomic force microscopy (AFM), and valence states of niobium ions were also investigated by optical absorption measurement. The electrochemical and photoelectrochemical reactions in the $\mathrm{ZnO}-$ and $\mathrm{NbO}_{\mathrm{x}^{-}}$ based PECs were discussed based on the experimental results.

\section{Experiment}

\subsection{Fabrication of Photovoltaic Electrodes}

Al thin films were deposited on a glass (SCHOTT Nippon K.K., Glass code: D263T) substrate by a radio frequency (RF) magnetron sputtering (SHINKO SEIKI CO., LTD, Type: SRV4320), where the deposition time was extended to $40 \mathrm{~min}$, obtaining $100 \mathrm{~nm}$ of Al films. The Al-coated glass substrate was also used as a counter electrode of PEC. $\mathrm{ZnO}$ or $\mathrm{NbO}_{\mathrm{x}}$ was deposited on the $\mathrm{Al} /$ glass substrate by $\mathrm{RF}$ magnetron reactive sputtering (ULVAC JAPAN, Ltd., Model: YH-500A or DIAVAC LIMITED, Type: DS-412Z, respectively). Figure 1 shows the structure of $\mathrm{ZnO}$ or $\mathrm{NbO}_{\mathrm{x}} / \mathrm{Al} /$ glass photovoltaic electrode. Table 1 shows the deposition conditions of $\mathrm{Al}, \mathrm{ZnO}$ and $\mathrm{NbO}_{\mathrm{x}}$, respectively.

\subsection{Electrochemical and Photoelectrochemical Measurements}

Figure 2 shows the schematic of PEC used in photoelectrochemical measurements. $\mathrm{KNO}_{3}$ solution was commonly used as an electrolyte solution in both the electrochemical and photoelectrochemical measurements. 


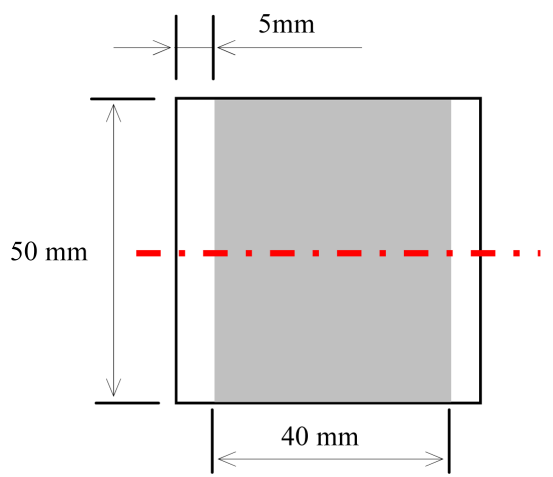

(a)

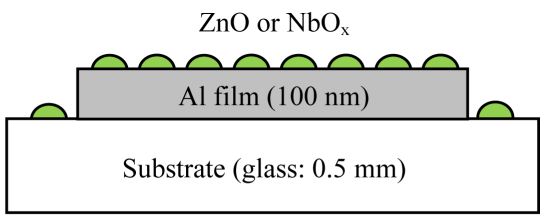

(b)

Figure 1. Schematic of photovoltaic electrode: (a) top view and (b) cross section.

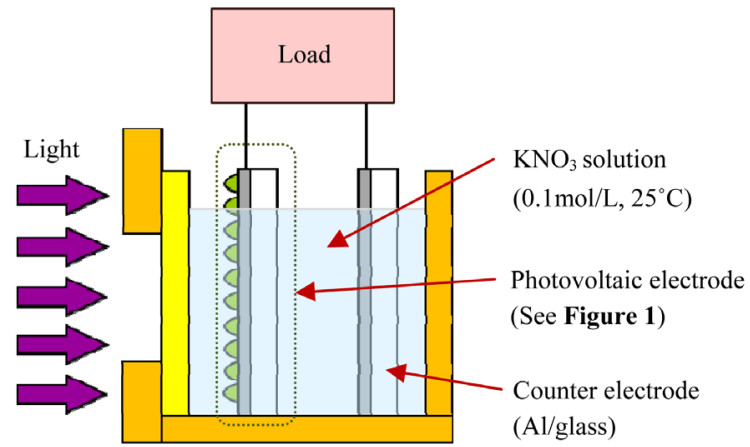

Figure 2. Schematic of PEC used in photoelectrochemical measurements.

Table 1. Deposition conditions of $\mathrm{Al}, \mathrm{ZnO}$ and $\mathrm{NbO}_{\mathrm{x}}$ by $\mathrm{RF}$ magnetron sputtering.

\begin{tabular}{|c|c|c|c|}
\hline & $\mathrm{Al}$ & $\mathrm{ZnO}$ & $\mathrm{NbO}_{\mathrm{x}}$ \\
\hline Substrate & Glass & Al/glass & $\mathrm{Al} /$ glass, quartz glass \\
\hline Target & $\phi 101.6$ mm, Al (99.9\%) & $\phi 50$ mm, Zn (99.99\%) & $\phi 50$ mm, Nb (99.99\%) \\
\hline Ar gas & $99.99 \%, 1.0 \mathrm{ccm}$ & $99.99 \%, 1.8 \mathrm{ccm}$ & $99.99 \%, 6.0 \mathrm{ccm}$ \\
\hline $\mathrm{O}_{2}$ gas & - & $99.99 \%, 2.4 \mathrm{ccm}$ & $99.99 \%, 6.0 \mathrm{ccm}$ \\
\hline Orbital speed of substrate holders & 1800 rpm & - & - \\
\hline Distance from substrate to target & $100 \mathrm{~mm}$ & $60 \mathrm{~mm}$ & $60 \mathrm{~mm}$ \\
\hline RF power, and frequency & $50 \mathrm{~W}, 13.56 \mathrm{MHz}$ & $200 \mathrm{~W}, 13.56 \mathrm{MHz}$ & $200 \mathrm{~W}, 13.56 \mathrm{MHz}$ \\
\hline Back pressure & $<8.0 \times 10^{-5} \mathrm{~Pa}$ & $<6.7 \times 10^{-4} \mathrm{~Pa}$ & $<6.7 \times 10^{-4} \mathrm{~Pa}$ \\
\hline Deposition pressure & $9.3 \times 10^{-2} \mathrm{~Pa}$ & $0.39 \mathrm{~Pa}$ & $0.39 \mathrm{~Pa}$ \\
\hline Deposition rate & $0.042 \mathrm{~nm} / \mathrm{s}$ & $1 \mathrm{~nm} / \mathrm{s}$ & $0.17 \mathrm{~nm} / \mathrm{s}$ \\
\hline Deposition time & $2400 \mathrm{~s}$ & $3,17 \mathrm{~s}$ & $10-300 s$ \\
\hline
\end{tabular}

$\mathrm{KNO}_{3}$ was dissolved in a distilled water (Wako Pure Chemical Industries, Ltd., CAS No.: 7732-18-5, 200 ml), obtaining $0.1 \mathrm{~mol} / \mathrm{L}$ electrolyte solution. During the measurements, the electrolyte solution was kept at a constant temperature of $25^{\circ} \mathrm{C}$, and the measurements were done in a dark place.

Firstly, the electrode potential was measured. The $\mathrm{ZnO}$ or $\mathrm{NbO}_{\mathrm{x}} / \mathrm{Al} /$ glass electrode and a carbon counter electrode (NaRiKa Corporation, CAT. NO. B10-2050-09) were immersed in the electrolyte solution. The electrodes 
were connected to a potentiostat (Bio Logic, SP-50), and an $\mathrm{Ag} / \mathrm{AgCl}$ electrode in saturated $\mathrm{KCl}$ solution (HOKUTO DENKO Co., HX-R6) was also connected as a reference electrode. The potential of the electrodes with respect to the reference electrode was determined by measuring open circuit voltage for $100 \mathrm{~s}$. Subsequently, electrochemical stability, that is, corrosion resistance of the electrodes was evaluated, where a constant load discharge (CLD) mode with an electrical resistance of $100 \mathrm{k} \Omega$ installed in the potentiostat was used. At this time, $\mathrm{Al} /$ glass soaked in a separate beaker was used as a counter electrode, and the beakers were connected with a $\mathrm{KNO}_{3}$ salt bridge. Elution of $\mathrm{Nb}, \mathrm{Zn}$ and $\mathrm{Al}$ in the electrodes was investigated after immersing the electrodes for 1 hour. Inductively coupled plasma measurement (SEIKO and VARIAN Inst., Vista-PRO CCD Simultaneous ICP-OES) was used for the detection of the elements eluted in the electrolyte solution.

In the evaluation of photoelectrochemical properties, photocurrent generation was firstly measured by using the PEC shown in Figure 2, where a solar simulator (SAN-EI ELECTRIC, XES-40S1, Irradiance: $1000 \mathrm{~W} / \mathrm{m}^{2}$ ) was used as a light source. The CLD mode with $100 \mathrm{k} \Omega$ resistance installed in the potentiostat apparatus was also used in the photocurrent measurements. During the measurements, voltage was not controlled by the potentiostat, and only the current passing through the resistance in the potentiostat apparatus was measured. The $\mathrm{ZnO}$ or $\mathrm{NbO}_{\mathrm{x}}$ side of the photovoltaic electrodes was exposed to a simulated sunlight generated by the solar simulator. The power supply of the potentiostat was turned on. After waiting for $100 \mathrm{~s}$ without irradiation, the light emitted from the solar simulator was irradiated to the photovoltaic electrode for $300 \mathrm{~s}$. The irradiation was repeated for 9 times at an interval of $100 \mathrm{~s}$, and the total measurement time was $3600 \mathrm{~s}$. After the measurements, elution of the electrode constituents was also evaluated by ICP.

Finally, electricity generation property was investigated by measuring current and voltage generated by the light irradiation. In the measurement, the cell setup given in Figure 2 was also used, and a variable resistor (YOKOGAWA ELECTROC WORKS. LTD., Decade Resistance Box Type 2793, Max: 111.1110 M $\Omega$ ) was, however, connected to the electrodes instead of the constant load. The current and voltage were measured by using multimeters (Agilent Technologies, Inc., Agilent 34,450 A 5 1/2 Digit Multimeter). Photocurrent and photovoltage were measured by changing resistance. Dark current and voltage measurement without light irradiation was also carried out, and net electricity generation was evaluated by subtracting dark current and voltage from photocurrent and photovoltage.

\subsection{Surface Observation by AFM}

In the previous report [12], ZnO nano-islands were not distinguished clearly by AFM (Bruker AXS K.K., Dimension Icon). In the present study, a tapping mode AFM apparatus was also used, where a phase mode was applied to distinguish the $\mathrm{NbO}_{\mathrm{x}}$ or $\mathrm{ZnO}$ deposits from the $\mathrm{Al}$ thin film. In the phase mode, the difference in hardness of two substances, that is, metal and oxide, appears in the difference in phase angle, which can be used for the distinction.

\subsection{Measurement of Optical States}

In the previous study [12], X-ray diffraction (XRD) measurement (Rigaku Corporation, Ultima IV) indicated that $\mathrm{ZnO}$ deposits were crystalline. However, it was guessed that $\mathrm{NbO}_{\mathrm{x}}$ deposits were amorphous [27], and actually sharp peaks were not observed in XRD patterns. It is generally known that band gap of $\mathrm{Nb}_{2} \mathrm{O}_{5}$ is $3.4 \mathrm{eV}$, and it is hence expected that the stoichiometry of $\mathrm{NbO}_{\mathrm{x}}$ is estimated from the optical absorption edge. Then, optical absorption measurement was performed by using a double-beam spectrophotometer method (Shimadzu Corporation, UV-3100). For the measurement, $\mathrm{NbO}_{\mathrm{x}}$ were directly deposited on a quartz glass substrate (Sendai quartz glass Works, Co. Ltd., Synthetic quartz glass, SUPRASIL-P30) under the same conditions given in Table 1. Furthermore, the absorption spectra for the reagents, NbO (Kojundo Chemical Lab. Co., Ltd., Cat. No. $\mathrm{NBO} 01 \mathrm{~PB}), \mathrm{NbO}_{2}$ (NBO02PB), and $\mathrm{Nb}_{2} \mathrm{O}_{5}$ (NBO06PB) were also measured with an integrating sphere (JASCO Corporation, ISN-470) for comparison.

\section{Results}

\subsection{Electrochemical Property}

Electrode potentials are shown in Table 2. The electrode potential of $\mathrm{Al} / \mathrm{glass}(-0.70 \mathrm{~V}$ vs. $\mathrm{Ag} / \mathrm{AgCl})$, which is higher than the standard electrode potential of Al (-1.662 V vs. SHE, standard hydrogen electrode) [28]. The 
Table 2. Electrode potentials obtained by open circuit voltage measurement.

\begin{tabular}{|c|c|c|}
\hline Electrode & Deposition time (s) & Electrode potential (V vs. Ag/AgCl) \\
\hline $\mathrm{Al} /$ glass & - & -0.70 \\
\hline \multirow{2}{*}{$\mathrm{ZnO} / \mathrm{Al} /$ glass } & 3 & -0.55 \\
\hline & 17 & -0.46 \\
\hline \multirow{11}{*}{$\mathrm{NbO}_{\mathrm{x}} / \mathrm{Al} /$ glass } & 10 & -0.19 \\
\hline & 15 & -0.25 \\
\hline & 17 & -0.19 \\
\hline & 20 & -0.07 \\
\hline & 30 & -0.04 \\
\hline & 40 & 0.00 \\
\hline & 60 & 0.07 \\
\hline & 100 & 0.11 \\
\hline & 150 & 0.19 \\
\hline & 200 & 0.20 \\
\hline & 300 & 0.23 \\
\hline
\end{tabular}

electrode potentials of $\mathrm{ZnO}$ - and $\mathrm{NbO}_{\mathrm{x}}$-deposited electrodes are higher than those of the $\mathrm{Al} /$ glass electrodes. In $\mathrm{NbO}_{\mathrm{x}} / \mathrm{Al} /$ glass electrode, the electrode potential increases with increasing the deposition time, and similar trend is also seen in $\mathrm{ZnO} / \mathrm{Al} /$ glass electrode. During the potential measurements, the electrode potential of $\mathrm{NbO}_{\mathrm{x}}$-deposited electrodes was stable and almost constant with small fluctuation. In the case of ZnO-deposited electrodes, however, the electrode potential decreased continuously during the measurements, and the electrode with shorter deposition time had higher rate of decrease in electrode potential. The decrease in the electrode potential during the measurements suggests the two possible changes in the $\mathrm{ZnO}$-deposited electrodes, that is, the reduction of $\mathrm{Zn}$ from 2+ to 0 in valence number and the dissolution of $\mathrm{ZnO}$ deposits into the electrolyte solution.

After electrochemical corrosion tests, the elution of $\mathrm{Al}$ and $\mathrm{Zn}$ from $\mathrm{ZnO} / \mathrm{Al} /$ glass electrodes is confirmed, and such the elution is not observed in $\mathrm{NbO}_{\mathrm{x}} / \mathrm{Al} / \mathrm{glass}$ electrodes. The elution is discussed later.

\subsection{Photoelectrochemical Property}

Figure 3 shows the photocurrent density curves of $\mathrm{ZnO}$ - and $\mathrm{NbO}_{\mathrm{x}}$-based PECs. In these PECs, $\mathrm{ZnO}$ and $\mathrm{NbO}_{\mathrm{x}}$ were deposited for $3,17 \mathrm{~s}$ and 17, $100 \mathrm{~s}$ at the apparent deposition rates of 1.00 and $0.17 \mathrm{~nm} / \mathrm{s}$, respectively, expecting the comparable thicknesses of ca. 3 and $17 \mathrm{~nm}$. In the previous study [12], it was confirmed that ZnO deposits were present as nano-islands at these thicknesses. As shown in Figure 3, current generation during the light irradiation is successfully confirmed in the $\mathrm{NbO}_{\mathrm{x}}$-based PECs, where current generation is stable, and very little degradation is observed in current generation even after repeating irradiation. In case of the $\mathrm{ZnO}$ deposits, current decreases rapidly and changes into increase just before irradiation. Even after starting irradiation, current increases slowly and continuously, and in the case of 3 s ZnO-deposited PEC, current stops increasing at ca. $1700 \mathrm{~s}$. Even when light was not irradiated, almost the same current curves were obtained, suggesting that most of current obtained in the ZnO-based PECs was caused not by photoelectrochemical but by electrochemical reactions. However, only in $3 \mathrm{~s} \mathrm{ZnO}$-deposited PEC, small but clear decrease in current is recognized after stopping 4th irradiation, which indicates photocurrent generation by photo-induced electrochemical reactions. When the light irradiation is continued for a few hours or more, very small and few bubbles are generated at all the electrodes, that is, photovoltaic and counter electrodes in both $\mathrm{NbO}_{\mathrm{x}}$ and $\mathrm{ZnO}$-based PECs.

In the previous study of $\mathrm{ZnO}$ nano-islands [12], Al-etching under UV irradiation was observed, and as mentioned, the elution of $\mathrm{Zn}$ and $\mathrm{Al}$ in $\mathrm{ZnO} / \mathrm{Al} /$ glass electrode was also confirmed in dark place. Table 3 shows the concentrations of the elements eluted from $\mathrm{ZnO} / \mathrm{Al} /$ glass electrodes during the electrochemical corrosion tests 


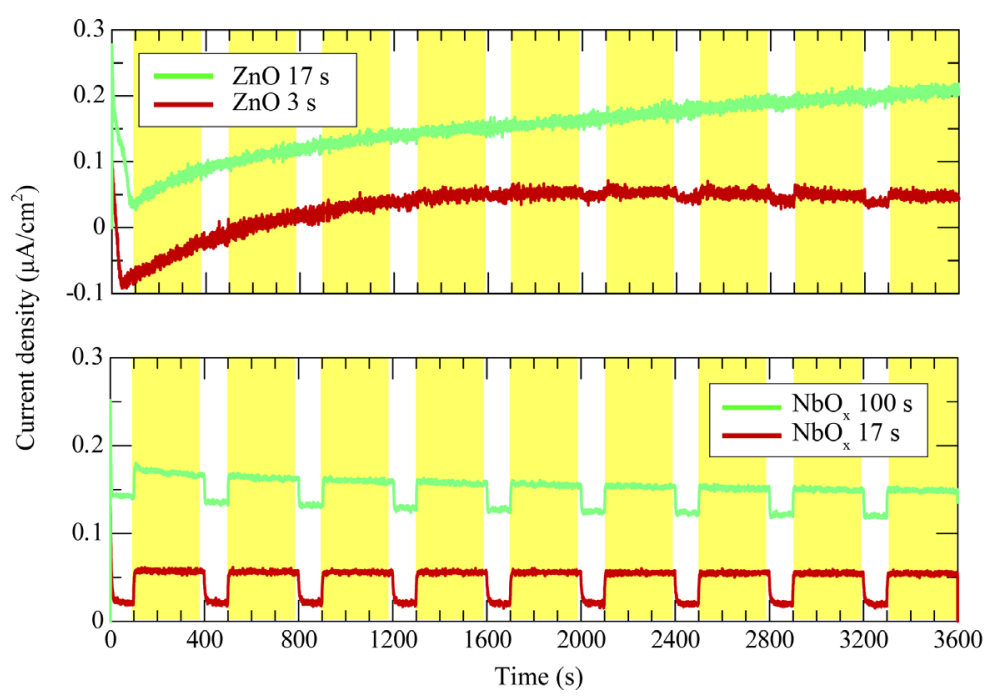

Figure 3. Photocurrent density curves of $\mathrm{ZnO}$ and $\mathrm{NbO}_{\mathrm{x}}$-based PECs prepared at different deposition times. Yellow regions show the light irradiating periods.

Table 3. Concentrations of the elements eluted from $\mathrm{ZnO} / \mathrm{Al} /$ glass electrodes during the electrochemical corrosion and photocurrent generation tests obtained by ICP measurement.

\begin{tabular}{cccc}
\hline Test & ZnO deposition time (s) & $\mathrm{Al}(\mathrm{ppb})$ & $\mathrm{Zn}(\mathrm{ppb})$ \\
\hline \multirow{2}{*}{ Corrosion } & 3 & 7 & 72 \\
& 17 & 8 & 80 \\
\hline \multirow{2}{*}{ Photocurrent generation } & 3 & 12 & 116 \\
& 17 & 28 & 143 \\
\hline
\end{tabular}

and photocurrent measurements. After the photocurrent measurements, $\mathrm{Zn}$ and $\mathrm{Al}$ were confirmed in the electrolyte solution, and the concentrations were larger as compared with the case without light irradiation. Therefore, it is supposed that the electrochemical reactions resulting in the elution of $\mathrm{Zn}$ and $\mathrm{Al}$ are accelerated by their radiation. In case of the $\mathrm{NbO}_{\mathrm{x}}$-based PECs, neither $\mathrm{Al}$ nor $\mathrm{Nb}$ elution was detected in the photovoltaic electrode. However, Al elution from the counter electrodes was confirmed in both PECs.

In both PECs, electrons flowed from the counter electrode into the photovoltaic electrode through the external circuit during light irradiation. The direction of electron flow was the same even in the electrochemically-unstable $\mathrm{ZnO}$-based PECs. According to the direction of electron flow, following reduction and oxidation reactions are expected at the photovoltaic and counter electrodes, respectively.

Photovoltaic electrode:

$$
\begin{aligned}
& \mathrm{NO}_{3}^{-}+\mathrm{H}_{2} \mathrm{O}+2 \mathrm{e}^{-} \rightarrow \mathrm{NO}_{2}^{-}+2 \mathrm{OH}^{-}, \\
& 2 \mathrm{H}^{+}+2 \mathrm{e}^{-} \rightarrow \mathrm{H}_{2}
\end{aligned}
$$

Counter electrode:

$$
\begin{aligned}
& \mathrm{Al} \rightarrow \mathrm{Al}^{3+}+3 \mathrm{e}^{-}, \\
& 4 \mathrm{OH}^{-} \rightarrow \mathrm{O}_{2}+2 \mathrm{H}_{2} \mathrm{O}+4 \mathrm{e}^{-}
\end{aligned}
$$

However, the current flow observed in the present study is opposite to the direction commonly observed in wet-type solar cells with semiconductor electrodes, such as $\mathrm{TiO}_{2}$ [29]-[31].

Figure 4 shows the relation between photocurrent density, $J$ and photovoltage, $V$ ( $J$ - $V$ curve) at different deposition time of $\mathrm{NbO}_{x}$. By subtracting dark current and dark voltage from photocurrent and photovoltage obtained at the same electrical resistance, the net photocurrent and photovoltage generated by light irradiation were estimated, obtaining the net $J-V$ curve. In general, gradual and steep decreases in photocurrent density at lower and higher photovoltage regions are expected in typical PECs, and in the PECs shown in Figure 4, however, an 


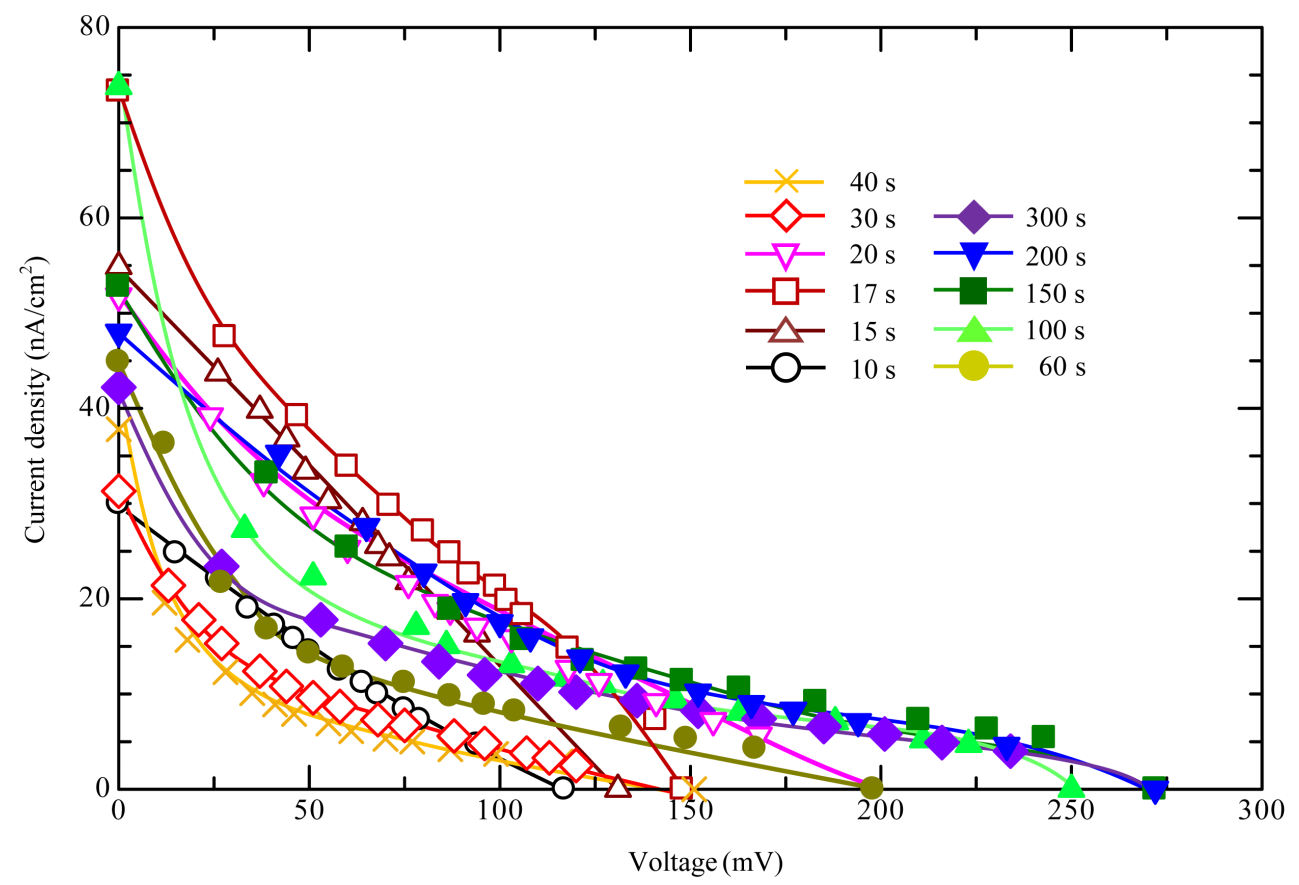

Figure 4. Photocurrent density vs. photovoltage $J$ - $V$ curves measured for the $\mathrm{NbO}_{\mathrm{x}}$-based PECs at different deposition time.

opposite change in $J-V$ curve is commonly observed, that is, steep and gradual decreases in $J$ are seen at lower and higher $V$ regions, respectively.

Then, fill factor, $F F$ is calculated from the equation, $F F=P_{\max } /\left(J_{\mathrm{sc}} \times V_{\mathrm{oc}}\right)$, where $P_{\max }$ is the maximum power density, $J_{\mathrm{sc}}$ is the short circuit current density, and $V_{\mathrm{oc}}$ is the open circuit voltage. Figure 5 shows $J_{\mathrm{sc}}, V_{\mathrm{oc}}, P_{\max }$ and $F F$ of the $\mathrm{NbO}_{\mathrm{x}}$-based PECs at the different $\mathrm{NbO}_{\mathrm{x}}$ deposition time. $J_{\mathrm{sc}}$ and $P_{\max }$ reach respective maxima of ca. $100 \mathrm{nA} / \mathrm{cm}^{2}$ and $2.9 \mathrm{nW} / \mathrm{cm}^{2}$ at the deposition time of $17 \mathrm{~s}$. FF reaches maximum of ca. $25 \%$ at the deposition time of $15 \mathrm{~s}$. $V_{\text {oc }}$ reaches maximum of ca. $270 \mathrm{mV}$ at the deposition time of $150 \mathrm{~s}$. $J_{\mathrm{sc}}$ and $P_{\max }$ indicate second maxima at the deposition times of 100 and $150 \mathrm{~s}$, respectively. The detail of photoelectrochemical conversion mechanism is discussed later.

\subsection{Surface Characterization by AFM}

Figure 6 shows the height images (a)-(e) and the phase images (f)-(j) obtained by AFM for the $\mathrm{NbO}_{\mathrm{x}} / \mathrm{Al} / \mathrm{glass}$ electrodes before the photoelectrochemical measurement. Comparing the height images, surface roughness of $\mathrm{NbO}_{\mathrm{x}}$-undeposited $\mathrm{Al} /$ glass substrate (Figure 6(a)) and $\mathrm{NbO}_{\mathrm{x}}$-deposited $\mathrm{NbO}_{\mathrm{x}} / \mathrm{Al} /$ glass substrates (Figures 6(b)-(d) at deposition time $\leq 40 \mathrm{~s}$ ) is almost unchanged. As for the phase images, the $\mathrm{NbO}_{\mathrm{x}}$-undeposited $\mathrm{Al} / \mathrm{glass}$ substrate indicates the phase angle of ca. $45^{\circ}$ (Figure 6(f)), which may correspond to oxidized surface layer of $\mathrm{Al}$ film. In the $\mathrm{NbO}_{\mathrm{x}}$-deposited specimens (Figures 6(g)-(j)), components with the phase angles of $-60^{\circ}$ and $0^{\circ}$ $45^{\circ}$ are confirmed. It is thought that these components are metallic $\mathrm{Al}$ and $\mathrm{NbO}_{\mathrm{x}}$, respectively, because the $0^{\circ}$ $45^{\circ}$ component increases with increasing the deposition time. It is supposed that the oxidized surface $\mathrm{Al}$ layer (phase angle $\left.=45^{\circ}\right)$ is removed or reduced to metallic state $\left(-60^{\circ}\right)$ by $\mathrm{NbO}_{\mathrm{x}}$ sputter deposition. In the phase images, nano-islands of $\mathrm{NbO}_{\mathrm{x}}$ deposits are also confirmed at the deposition time of $10 \mathrm{~s}$. The further deposition results in the growth and densification of $\mathrm{NbO}_{\mathrm{x}}$ islands at the deposition time of $40 \mathrm{~s}$ (Figure 6(i)), and the surface of $\mathrm{Al} /$ glass substrate is almost completely covered with a film of $\mathrm{NbO}_{\mathrm{x}}$ at the deposition time of $100 \mathrm{~s}$ (Figure 6(j)).

In Figure 6, two-dimensional phase images (k-n) are also shown, in which points with the phase angles larger than $-20^{\circ}$ are shown in white, which indicate $\mathrm{NbO}_{\mathrm{x}}$. At the deposition time $\leq 20 \mathrm{~s}$, growth of $\mathrm{NbO}_{\mathrm{x}}$ in an island state is confirmed. At the longer deposition time $=100 \mathrm{~s}, \mathrm{NbO}_{\mathrm{x}}$ are in a film state, and the underlying Al/glass substrate seems like lakes. Surface area of $\mathrm{NbO}_{\mathrm{x}}$ increases continuously with increasing the deposition time. 


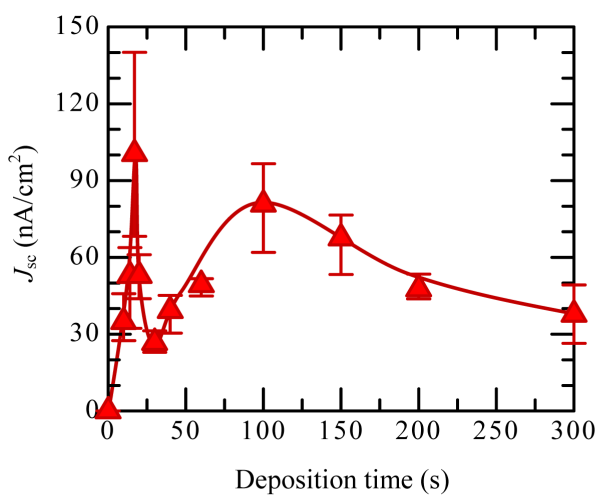

(a)

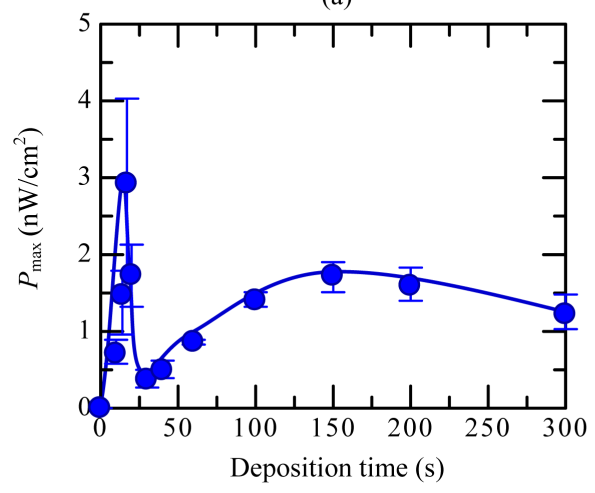

(c)

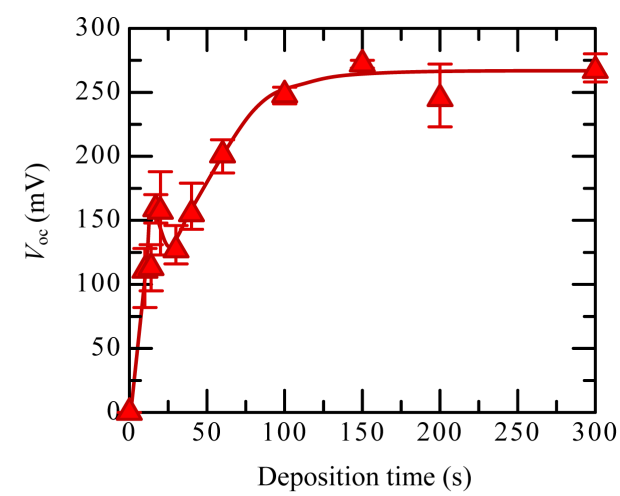

(b)

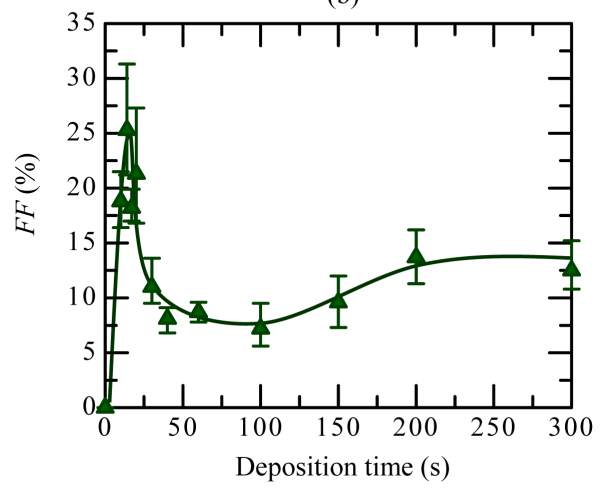

(d)

Figure 5. (a) Short circuit current density $\left(J_{\mathrm{sc}}\right)$, (b) open circuit voltage $\left(V_{\mathrm{oc}}\right)$, (c) maximum power density $\left(P_{\max }\right)$, and $(\mathrm{d})$ fill factor $(F F)$ of $\mathrm{NbO}_{\mathrm{x}}$-based PECs prepared at different deposition time.

After the photoelectrochemical measurement (Figure 3), AFM observation was performed again. Figure 7 shows AFM images and two dimensional images of the $\mathrm{NbO}_{\mathrm{x}} / \mathrm{Al} / \mathrm{glass}$ electrode at the $\mathrm{NbO}_{\mathrm{x}}$ deposition time of $17 \mathrm{~s}$ as-deposited and after 9 repetitions of photo irradiation in the photoelectrochemical measurement. During the repetitions, the electrode was kept in the electrolyte solution without being exposed to the atmosphere. In the AFM images, nano-island structures are confirmed, and quite little change is observed as compared with the asprepared specimen. On the other hand, in the Al/glass counter electrode (Figure 7(c)), surface roughness increases slightly as compared with the as-deposited one (Figure 6(a)), and the surface with phaseangle of ca. $0^{\circ}$ is newly found other than that of $45^{\circ}$ (Figure 7(f)). It is probably due to the Al elution. Figure 8 shows the AFM images of the $\mathrm{ZnO} / \mathrm{Al} /$ glass electrode with the $\mathrm{ZnO}$ deposition time of $3 \mathrm{~s}$. In the as-prepared electrode, nanoislands of $\mathrm{ZnO}$ deposits are confirmed (Figure 8(d)), and in the electrode after the 1st photoelectrochemical measurement, however, larger islands are also observed in the phase image (Figure 8(e)), and the surface roughness given in Figure 8(b) indicates a small change. The maximum phase angle increases slightly from 50 to $70^{\circ}$ in the electrodes before and after the photoelectrochemical measurement, suggesting that the surface is covered with some different substance other than $\mathrm{ZnO}$. After 9 repetitions of the light irradiation, the nano-islands grow higher, and the ditches become deeper, as shown in the height image (Figure 8(c)), and the surface is covered with a substance with large phase angle of $70^{\circ}$ (Figure 8(f)). The ditches reach a depth of $-16 \mathrm{~nm}$, corresponding to $1 / 6$ of the thickness of $\mathrm{Al}$ film $(100 \mathrm{~nm})$. As mentioned, $\mathrm{Al}$ and $\mathrm{Zn}$ elution from $\mathrm{ZnO} / \mathrm{Al} / \mathrm{glass}$ electrodes is confirmed, and it is therefore supposed that $\mathrm{Al}$ film and $\mathrm{ZnO}$ deposits are eluted in the electrolyte solution, and the eluted $\mathrm{Al}$ and $\mathrm{Zn}$ species are re-precipitated as solids, probably $\mathrm{Al}(\mathrm{OH})_{3}$ and $\mathrm{Zn}(\mathrm{OH})_{2}$, which cover for the electrode surface.

\subsection{Optical Absorption and Valence State of Niobium Ions}

Figure 9 shows the optical absorption spectra of $\mathrm{NbO}_{\mathrm{x}}$ deposited on a quartz glass substrate, in which those of the reagent powders of $\mathrm{NbO}, \mathrm{NbO}_{2}$, and $\mathrm{Nb}_{2} \mathrm{O}_{5}$ are also shown for comparison. In the absorption spectra of 


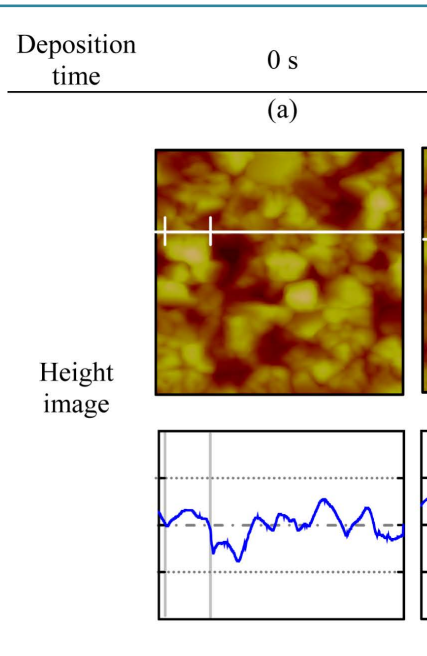

(f)
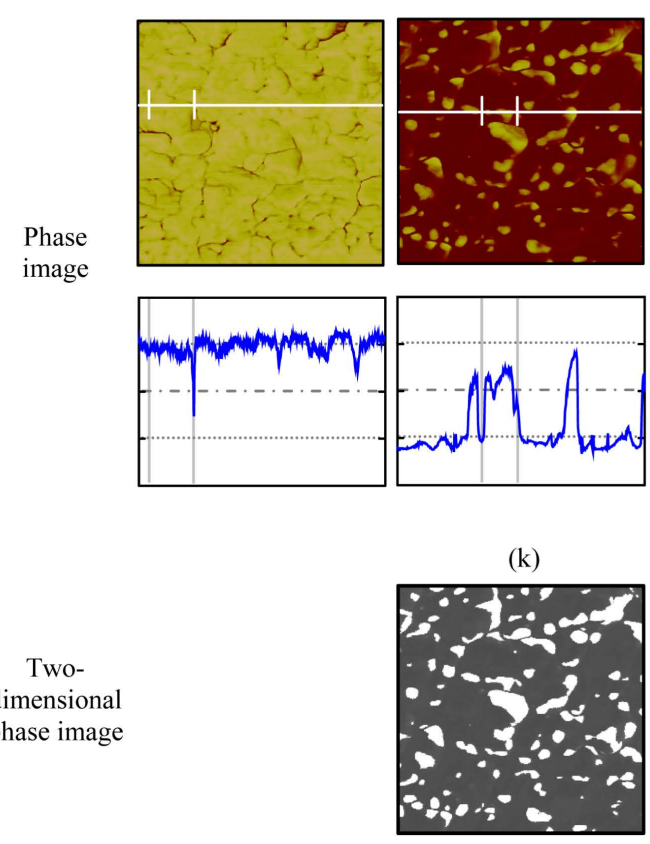

Two-

dimensional

phase image (k)

$20 \mathrm{~s}$

(c)
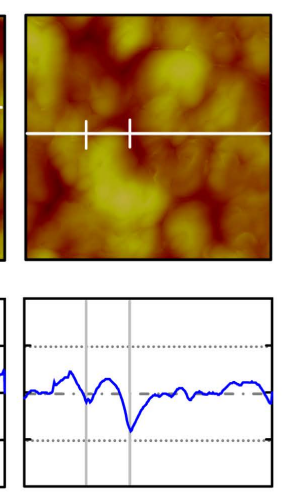

(h)
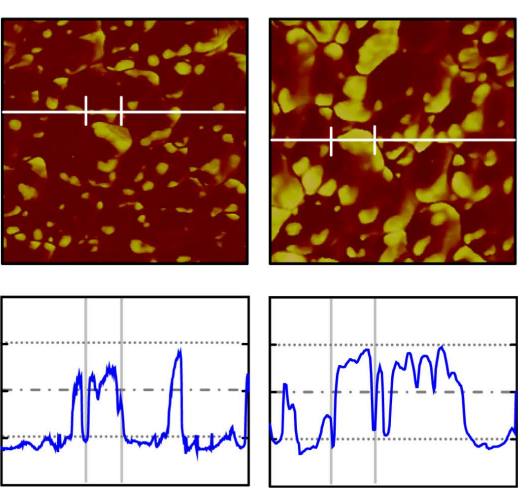

(1)

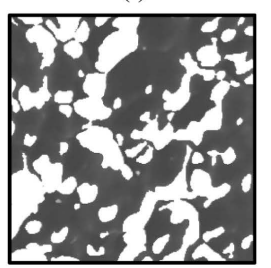

$40 \mathrm{~s}$

(d)
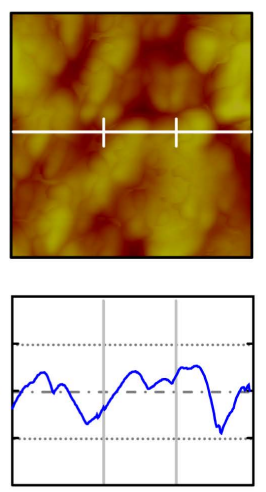

(i)
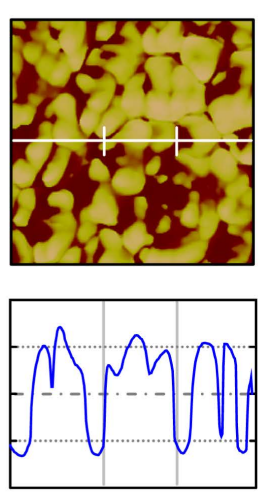

(m)

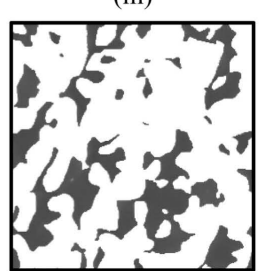

$100 \mathrm{~s}$

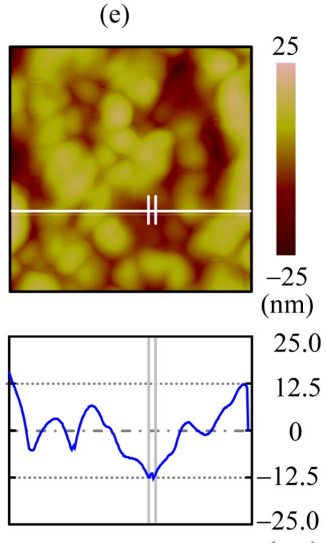

(nm)

(j)

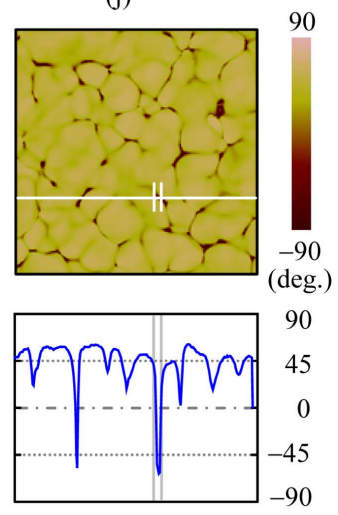

(deg.)

(n)

Figure 6. AFM images (height: (a)-(e), phase: (f)-(j)) of the as-prepared $\mathrm{NbO}_{\mathrm{x}} / \mathrm{Al} /$ glass electrodes at the different $\mathrm{NbO}_{\mathrm{x}}$ deposition time. Line scans were done at the horizontal lines drawn in the two dimensional images. Points with the phase angle $>$ $-20^{\circ}$ corresponding to $\mathrm{NbO}_{\mathrm{x}}$ deposits are indicated by white in two-dimensional phase images (k)-(n) $(500 \mathrm{~nm})$.

$\mathrm{NbO}_{\mathrm{x}}$ deposits, a leading edge is commonly confirmed at ca. $2.9 \mathrm{eV}$, which is close to the absorption edge of $\mathrm{Nb}_{2} \mathrm{O}_{5}$ reagent powder. For the $\mathrm{NbO}_{\mathrm{x}}$ deposits, a steep increase in the slope of absorption curves is also recognized at $3.5-3.7 \mathrm{eV}$, which is close to the band gap of $3.4 \mathrm{eV}$ generally known for $\mathrm{Nb}_{2} \mathrm{O}_{5}$. In our measurement, however, the optical band gap of $\mathrm{Nb}_{2} \mathrm{O}_{5}$ reagent powder is ca. $3.1 \mathrm{eV}$, which is smaller than the energy gap of $3.4 \mathrm{eV}$ given in literatures, and it is hence suggested that the $\mathrm{NbO}_{\mathrm{x}}$ deposits have different electronic state or atomistic structure from $\mathrm{Nb}_{2} \mathrm{O}_{5}$ crystal. Actually, no crystalline diffraction peaks are observed in XRD patterns of the $\mathrm{NbO}_{\mathrm{x}}$ deposits, indicating that the $\mathrm{NbO}_{\mathrm{x}}$ deposits are in amorphous state. It is supposed that the amorphous state of the $\mathrm{NbO}_{\mathrm{x}}$ deposits is due to oxygen deficiency, and it is also expected that part of $\mathrm{Nb}$ ions are reduced to $4+$ or $2+$ from $5+$. The reagent powders of crystalline $\mathrm{NbO}_{2}$ and $\mathrm{NbO}$ consisting of lower valency of niobium ions show strong absorption in almost the entire region. The $\mathrm{NbO}_{\mathrm{x}}$ deposits indicate quite different absorption spectra from $\mathrm{NbO}_{2}$ and $\mathrm{NbO}$. Therefore, it is difficult to estimate the valence state of niobium ions in the $\mathrm{NbO}_{\mathrm{x}}$ deposits, but it is supposed that most of $\mathrm{Nb}$ ions are present as $5+$. 


\begin{tabular}{cccc} 
Electrode & As-deposited & NbO $/$ Al/glass & Al/glass \\
& $\mathrm{NbO}_{\mathrm{x}} / \mathrm{Al} /$ glass & after 9 repetitions & after 9 repetitions \\
\hline
\end{tabular}
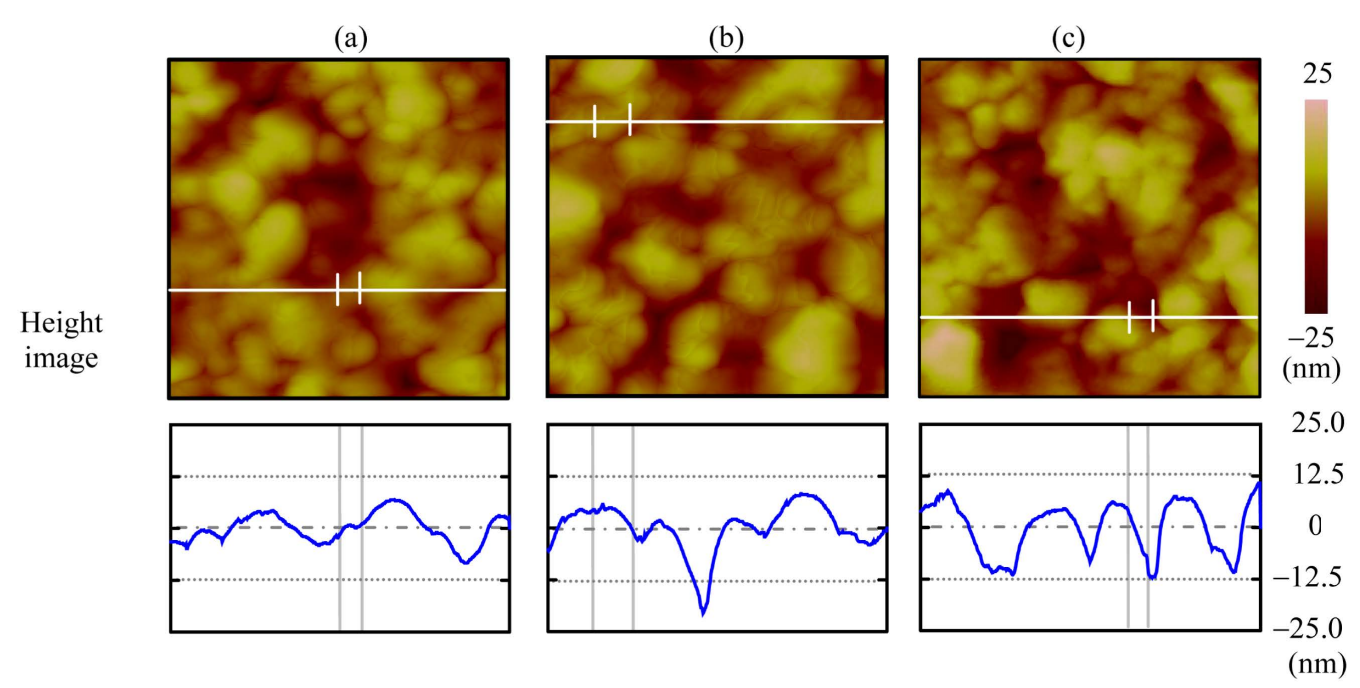

(d)

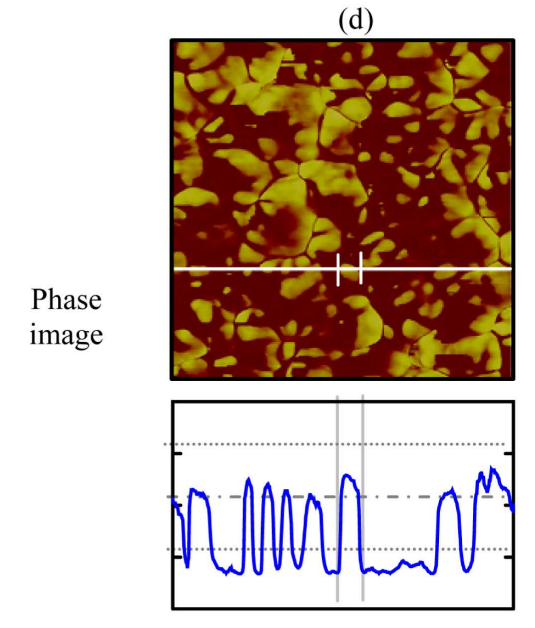

(g)
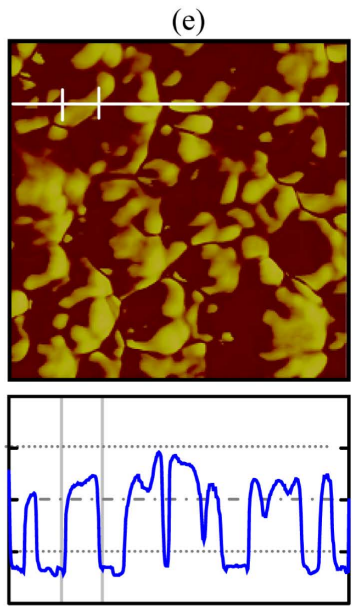

(h)
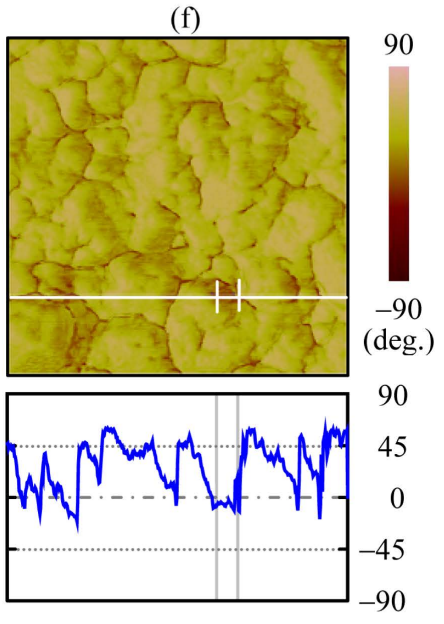

(deg.)

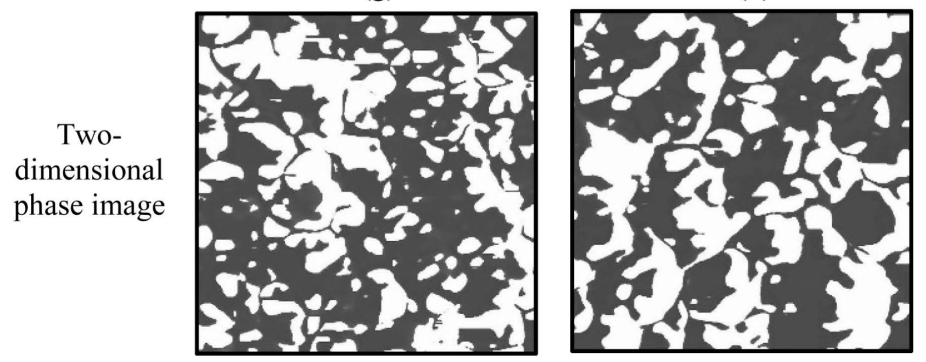

Figure 7. AFM images of $\mathrm{NbO}_{\mathrm{x}} / \mathrm{Al} /$ glass electrode $\left(\mathrm{NbO}_{\mathrm{x}}\right.$ deposition time $\left.=17 \mathrm{~s}\right)$ as-deposited and after 9 repetitions of photo irradiation in the photoelectrochemical measurement (Figure 3). AFM images of Al/glass counter electrode after the photoelectrochemical measurement are also shown (500 nm).

\section{Discussion}

\subsection{Electrochemical Reactions}

As mentioned, the elution of $\mathrm{Al}$ and $\mathrm{Zn}$ from $\mathrm{ZnO} / \mathrm{Al} /$ glass electrodes is observed regardless of light irradiation, 


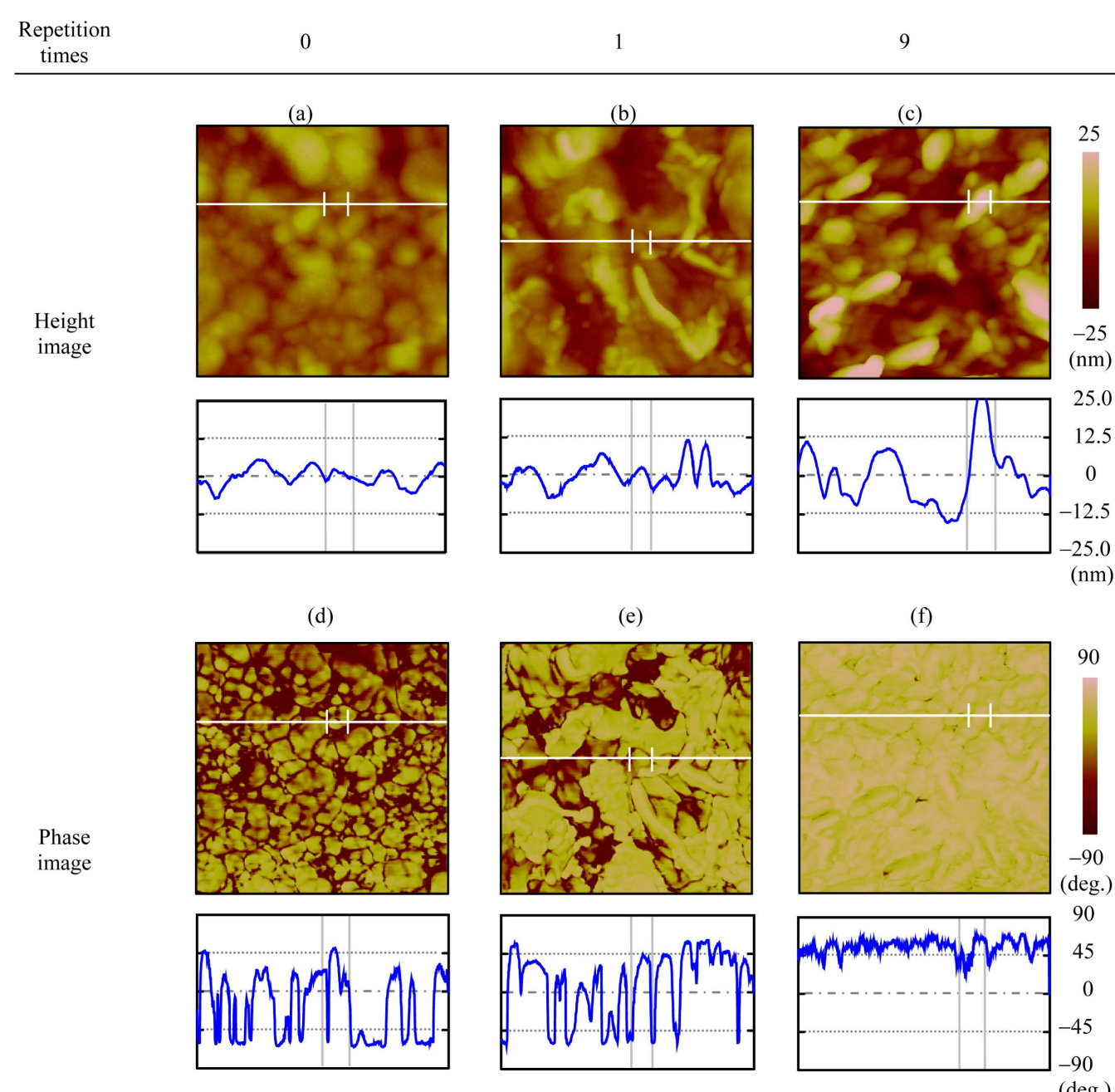

(deg.)

Figure 8. AFM images of the $\mathrm{ZnO} / \mathrm{Al} /$ glass electrode at the $\mathrm{ZnO}$ deposition time of $3 \mathrm{~s}$ before and after repetitions of photoelectrochemical measurement. Line scans were done at the horizontal lines drawn in the two dimensional images $(500 \mathrm{~nm})$.

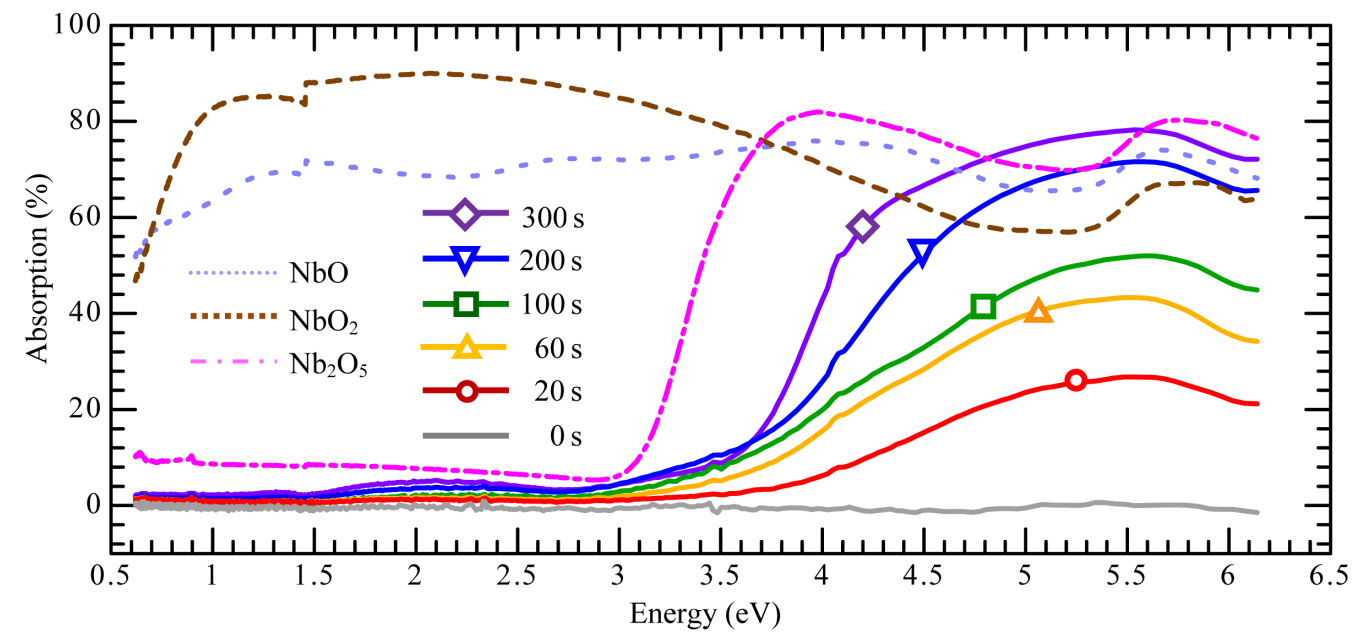

Figure 9. Absorption spectra of $\mathrm{NbO}_{\mathrm{x}}$ deposits on a quartz glass substrate obtained by double beam transmission measurement and reagent powders of $\mathrm{NbO}, \mathrm{NbO}_{2}$, and $\mathrm{Nb}_{2} \mathrm{O}_{5}$ measured with an integrating sphere. 
and such the elution is not recognized in $\mathrm{NbO}_{\mathrm{x}} / \mathrm{Al} /$ glass electrodes, which are explainable by the electrochemical corrosion based on potential-pH diagrams [32]. It is known that $\mathrm{ZnO}$ is dissolved in acidic and alkaline water but is not soluble in neutral water [33] [34]. It is also known that metallic aluminum is easily corroded by water, and in practice, however, surface $\mathrm{Al}$ is oxidized to be covered with insoluble and passive $\mathrm{Al}_{2} \mathrm{O}_{3}$ skins, which prevents $\mathrm{Al}$ corrosion in neutral water [35] [36]. Even in neutral water, Al may be corroded by some corrosion processes, such as galvanic, crevice and pitting corrosions. In galvanic corrosion, a base metal with lower electrode potential will work as anode and corrodes in the combination with noble materials having higher electrode potential. As shown in Table 2, Al/glass has the lowest electrode potential among the electrode constituents. If the galvanic corrosion were predominant, $\mathrm{Al}$ elution from $\mathrm{NbO}_{\mathrm{x}} / \mathrm{Al} /$ glass electrodes would be observed. However, $\mathrm{Al}$ elution is confirmed only in the $\mathrm{ZnO} / \mathrm{Al} /$ glass electrodes, and it is hence supposed that the galvanic corrosion is not responsible for the $\mathrm{Al}$ elution from the $\mathrm{ZnO} / \mathrm{Al} /$ glass electrodes.

Figure 10 shows that the magnified AFM images of the $\mathrm{ZnO} / \mathrm{Al} /$ glass and $\mathrm{NbO}_{\mathrm{x}} / \mathrm{Al} /$ glass electrodes at the

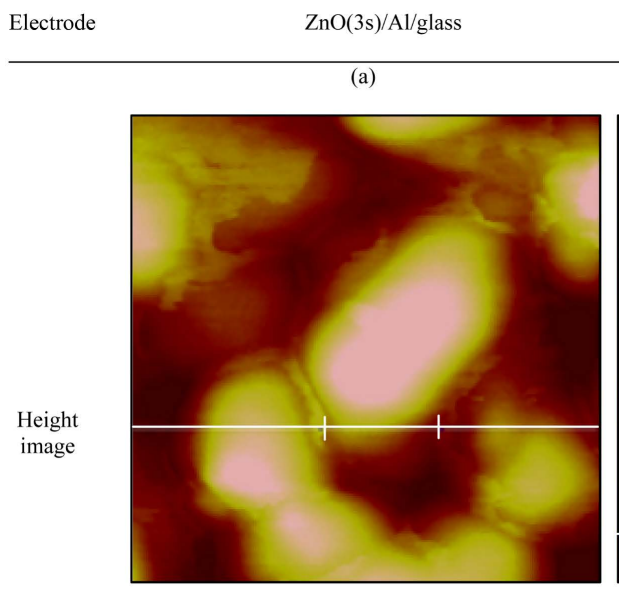

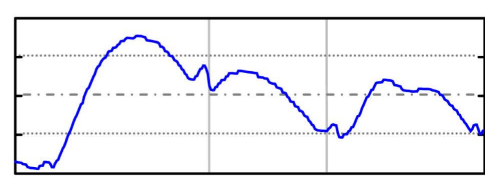

(c)
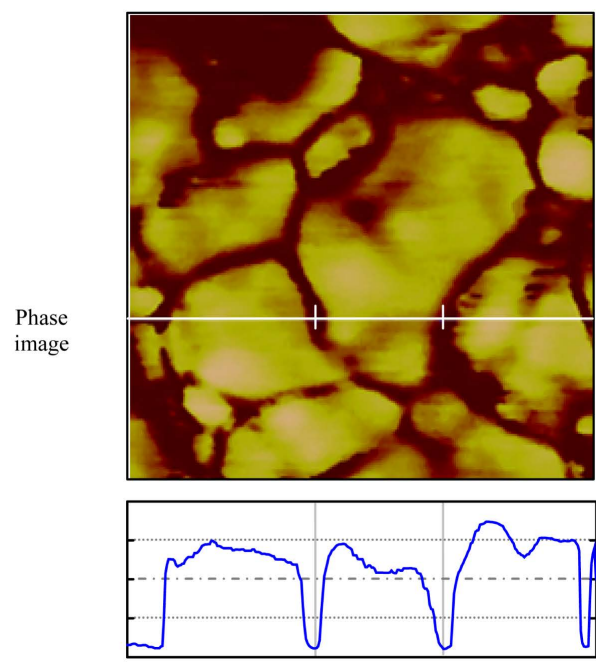

$\mathrm{NbO}_{x}(17 \mathrm{~s}) / \mathrm{Al} / \mathrm{glass}$

(b)
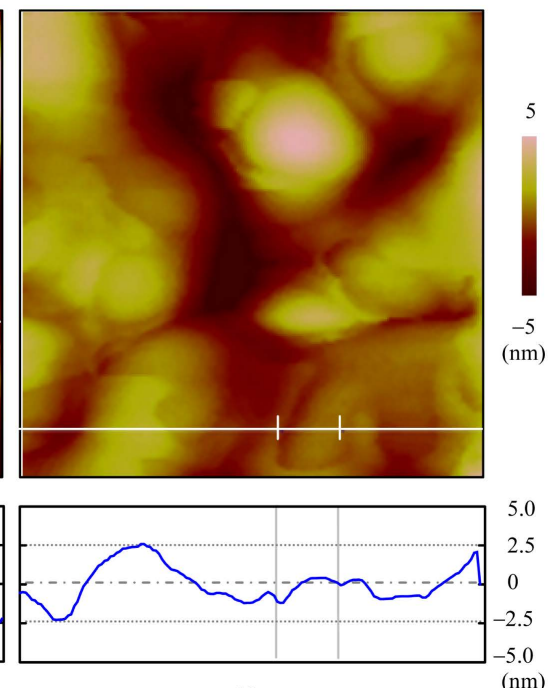

(d)
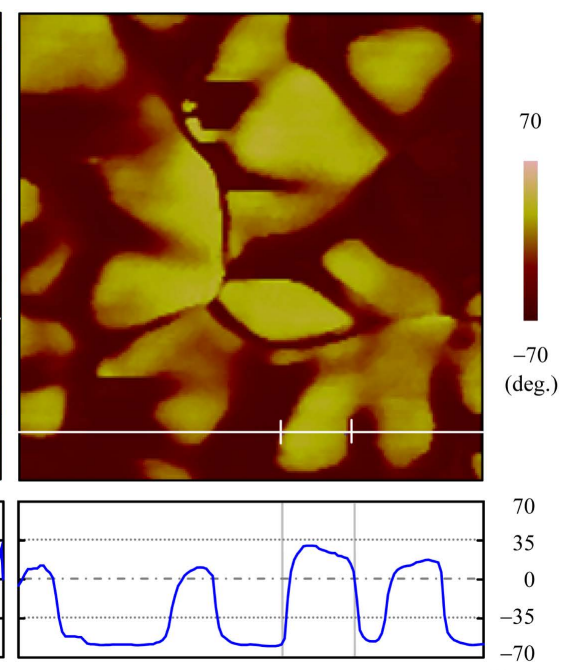

Figure 10. Magnified AFM images of the $\mathrm{ZnO} / \mathrm{Al} /$ glass and $\mathrm{NbO}_{\mathrm{x}} / \mathrm{Al} /$ glass electrodes at the deposition time of 3 and $17 \mathrm{~s}$, respectively. Line scans were done at the horizontal lines drawn in the two dimensional images $(150 \mathrm{~nm})$. 
deposition times of 3 and 17 s, respectively. Nano-dips with the depth of ca. $1 \mathrm{~nm}$ at brinks of nano-islands (vertical lines in Figure 10) are observed in both electrodes, which are probably produced by sputtering damages. At the dips in $\mathrm{Al}$ films, passive $\mathrm{Al}_{2} \mathrm{O}_{3}$ skins should be removed, and metallic $\mathrm{Al}$ might be exposed. Some of the dips should be covered with $\mathrm{ZnO}$ and $\mathrm{NbO}_{\mathrm{x}}$ deposits, and therefore, pitting and/or crevice corrosions are more likely to occur at the $\mathrm{Al} /$ glass surface. The supposed corrosion mechanism for $\mathrm{ZnO} / \mathrm{Al} /$ glass electrode is illustrated in Figure 11. The pitting and crevice corrosions are initiated by an anode reaction, $\mathrm{Al} \rightarrow \mathrm{Al}^{3+}+3 \mathrm{e}^{-}$. The electrons migrate toward $\mathrm{ZnO}$ deposits, because $\mathrm{ZnO}$ has higher electrode potential than $\mathrm{Al}$ (Table 2). When oxygen is dissolved in neutral water, a cathode reaction, $\mathrm{O}_{2}+2 \mathrm{H}_{2} \mathrm{O}+4 \mathrm{e}^{-} \rightarrow 4 \mathrm{OH}^{-}$is expected at the surface of $\mathrm{ZnO}$ deposits, resulting in $\mathrm{Al}(\mathrm{OH})_{3}$ precipitation [36]. After consuming dissolved oxygen in pits and crevices, a hydrolysis reaction of $\mathrm{Al}^{3+}$ ions, $\mathrm{Al}^{3+}+3 \mathrm{H}_{2} \mathrm{O} \rightarrow \mathrm{Al}(\mathrm{OH})_{3}+3 \mathrm{H}^{+}$will be induced, and $\mathrm{pH}$ in the pits and crevices subsequently reduces. In acidic water in the pits and crevices promotes the corrosion of $\mathrm{Al}$ and dissolution of $\mathrm{Al}(\mathrm{OH})_{3}$. At the same time, $\mathrm{ZnO}$ deposits which cover the crevices should be also dissolved by the acidic water, $\mathrm{ZnO}+2 \mathrm{H}^{+} \rightarrow \mathrm{Zn}^{2+}+\mathrm{H}_{2} \mathrm{O}$ [37]. It is known that $\mathrm{Nb}_{2} \mathrm{O}_{5}$ is soluble in neutral water [38], and as shown in Table 2, however, $\mathrm{NbO}_{\mathrm{x}} / \mathrm{Al} /$ glass electrodes have higher electrode potential than $\mathrm{Al} /$ glass substrate. It is hence supposed that $\mathrm{NbO}_{\mathrm{x}}$ deposits are less corroded than $\mathrm{Al}$ films on glass. If $\mathrm{Al}$ films are corroded and $\mathrm{pH}$ in crevice water reduces, $\mathrm{NbO}_{\mathrm{x}}$ deposits which cover the crevices should not be dissolved, because $\mathrm{Nb}$ ions in $\mathrm{NbO}_{\mathrm{x}}$ deposits are almost present with valency of $5^{+}$, and $\mathrm{Nb}_{2} \mathrm{O}_{5}$ is insoluble and passive for acidic water [38]. In these ways, the elution of $\mathrm{Al}$ and $\mathrm{Zn}$ only from $\mathrm{ZnO} / \mathrm{Al} /$ glass electrodes is explainable based on the pitting and/or crevice corrosions and the subsequent $\mathrm{pH}$ change of water in the pits and crevices. The passivation of $\mathrm{NbO}_{\mathrm{x}}$ deposits is also described based on the potential-pH diagram.

\subsection{Photoelectrochemical Reactions}

As shown in Figure 5, the maximum power density, $P_{\max }$ is not proportional to the deposition time of $\mathrm{NbO}_{\mathrm{x}}$ deposits, and the maximum $P_{\max }$ is obtained at the deposition time of $17 \mathrm{~s}$. As shown in Figure 9, the optical absorption increases almost linearly with increasing the deposition time of $\mathrm{NbO}_{\mathrm{x}}$, and shift of the optical band gap is not observed, suggesting that the valence state and atomistic structure of $\mathrm{NbO}_{\mathrm{x}}$ deposits remain unchanged even in the longer deposition time.

As above mentioned, during light irradiation, electrons flow from the counter electrode into the photovoltaic electrode through the external circuit, and at the same time, very small and few bubbles are formed. Moreover, $\mathrm{Al}$ elution from the counter electrodes is observed in the $\mathrm{ZnO}$ - and $\mathrm{NbO}_{\mathrm{x}}$-based PECs. Hence, electrochemical reactions given in Equations (1) and (2) are suggested, that is, reduction of nitrate ions and $\mathrm{H}_{2}$ generation by reduction reactions at the photovoltaic electrodes and $\mathrm{Al}$ elution and $\mathrm{O}_{2}$ generation by oxidation reactions at the counter electrode.

In the case of $\mathrm{NbO}_{\mathrm{x}}$ deposits, the electrons consumed in the reduction reactions are probably provided from the $\mathrm{NbO}_{\mathrm{x}}$ deposits, in which the electrons are excited into the conduction band by absorbing the irradiated light. It is also supposed that the reduction reactions occur at the interface between $\mathrm{NbO}_{\mathrm{x}}$ deposits and electrolyte

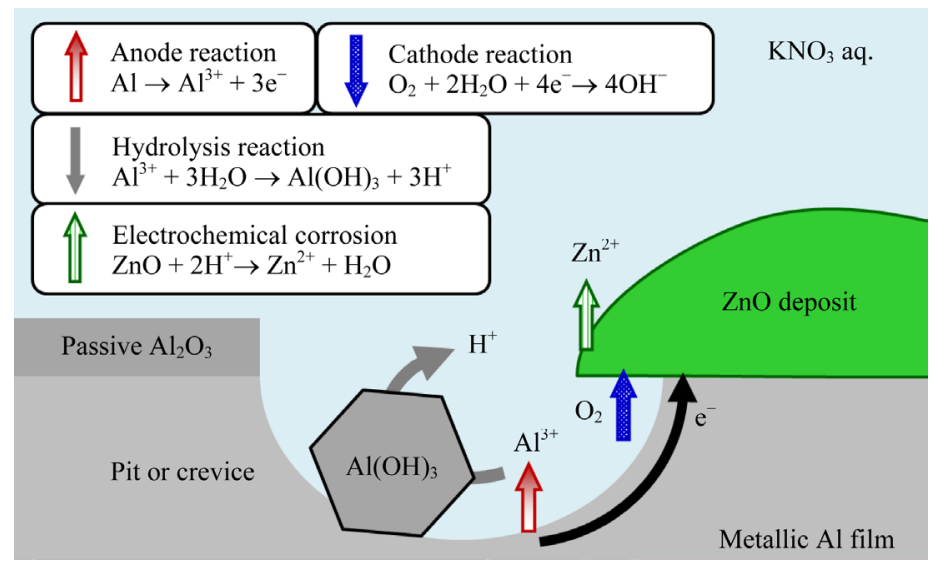

Figure 11. Electrochemical corrosion mechanism of $\mathrm{Al}$ and $\mathrm{ZnO}$ from the $\mathrm{ZnO} / \mathrm{Al} /$ glass electrode in the cell of $\mathrm{ZnO} / \mathrm{Al} /$ glass $\mid \mathrm{KNO}_{3}$ aq.|Al/glass. 
solution. However, the maximum power density is not proportional to the $\mathrm{NbO}_{\mathrm{x}}$ deposition time, and it is hence suggested that the reduction reactions occur only at the restricted surface of the $\mathrm{NbO}_{\mathrm{x}}$ deposits. It is consequently considered that most of the electrons excited by optical absorption are consumed to recombine with the holes created at the same time, and the residual holes are presumably filled with the electrons supplied from the external circuit through the $\mathrm{Al}$ film on the substrate electrode.

$\mathrm{NbO}_{\mathrm{x}}$ is probably an n-type semiconductor as well as $\mathrm{Nb}_{2} \mathrm{O}_{5}$. When a semiconductor electrode is soaked in an electrolyte solution with different electrostatic potential, a potential bending occurs in the electrode surface, which induces migrations of electrons and holes. In case of the $\mathrm{NbO}_{\mathrm{x}}$-based PEC, it is expected that electrons are concentrated at the surface of $\mathrm{NbO}_{\mathrm{x}}$ deposits, and if present, holes migrate toward the underlying $\mathrm{Al}$ film. In the case of nano-islands, the thickness is too small to bend the surface potential, resulting in almost no potential gradient, which is similar to a flat-band state. In flat-band state, mobility and migration distance of electrons and holes are quite small, and it is hence expected that only the holes produced very near the Al film recombine with electrons which are supplied through the $\mathrm{Al}$ film. It is consequently supposed that the photoelectrochemical reactions proceed in the immediate vicinity of the boundary among $\mathrm{NbO}_{\mathrm{x}}$ nano-island, $\mathrm{Al}$ film, and electrolyte solution.

Then, the boundary is estimated from the two-dimensional AFM phase images given in Figure 6, in which the boundary between the $\mathrm{NbO}_{\mathrm{x}}$ deposits and the underlying $\mathrm{Al}$ film also means the boundary with the electrolyte solution. Figure 12 shows the boundary length obtained from an image analysis of Figure 6. For comparison, projected area of the $\mathrm{NbO}_{\mathrm{x}}$ deposits was estimated from Figure 6, and the results are also given in Figure 12. The boundary length becomes the longest at the $\mathrm{NbO}_{\mathrm{x}}$ deposition time of $17 \mathrm{~s}$, which is consistent with the deposition time obtaining the maximum photocurrent density $\left(J_{\mathrm{sc}}\right)$ and power density $\left(P_{\max }\right)$ shown in Figure 5. The $\mathrm{NbO}_{\mathrm{x}}$ projected area increases continuously with increasing the deposition time, and the slope changes at around the deposition time of $40 \mathrm{~s}$, suggesting the change in growth direction of the islands from horizontal to vertical.

As shown in Figure 12(a), boundary length decreases continuously with increasing the $\mathrm{NbO}_{\mathrm{x}}$ deposition time > $17 \mathrm{~s}$. In $J_{\mathrm{sc}}$ and $P_{\max }$, however, second maxima are observed at the $\mathrm{NbO}_{\mathrm{x}}$ deposition times of 100 and $150 \mathrm{~s}$, respectively (Figure 5). As mentioned, $\mathrm{NbO}_{\mathrm{x}}$ deposits grow in the vertical direction at the deposition time $>40 \mathrm{~s}$, and it is hence supposed that the thickness of $\mathrm{NbO}_{\mathrm{x}}$ islands and films increases continuously. In these specimens, $\mathrm{NbO}_{\mathrm{x}}$ deposits should have enough thickness to yield potential bending, from which electrons and holes generated by photo irradiation are able to migrate in the thickness direction and reach the outermost surface and innermost bottom surface of $\mathrm{NbO}_{\mathrm{x}}$ deposits, resulting in the photoelectrochemical conversion.

Figure 13 shows the photoelectrochemical conversion mechanism proposed for the $\mathrm{NbO}_{\mathrm{x}}$-based PECs. In the case of nano-islands, it is supposed that the photoelectrochemical reactions in the photovoltaic electrodes take place just around the boundary, and hence most of the deposits far from the boundary should have little contribution to the electric power generation. In the case of film, it is also suggested that the photoelectrochemical conversion reactions occur at the film surface, and the reactions, however, should be restricted at part of the

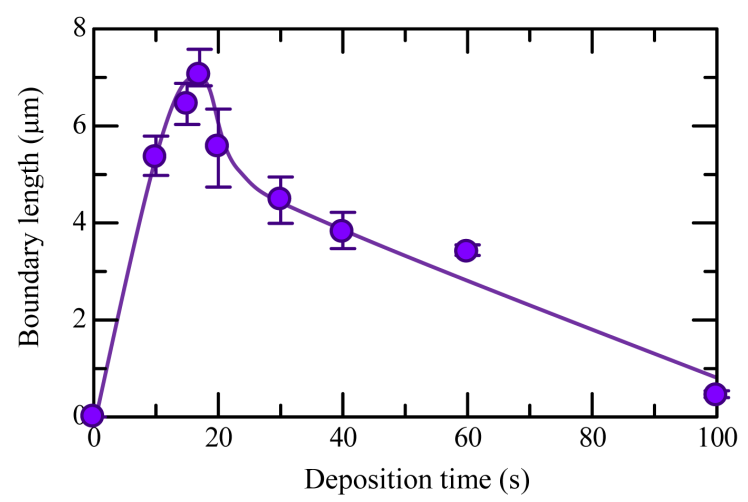

(a)

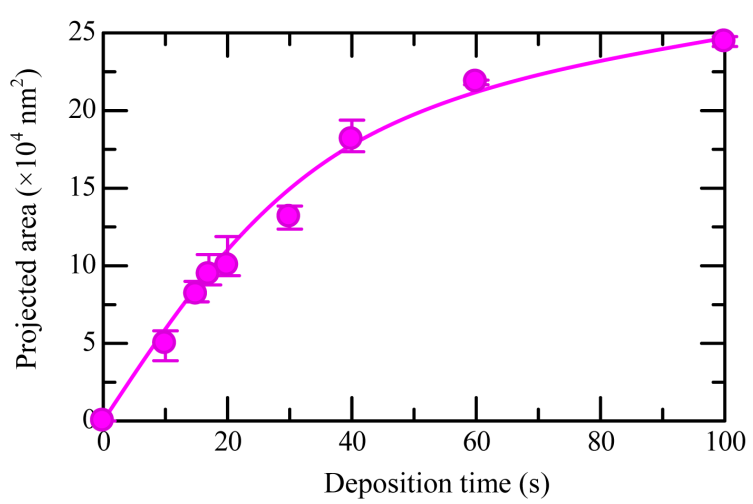

(b)

Figure 12. (a) Length of the boundary among $\mathrm{NbO}_{\mathrm{x}}$ deposits, underlying $\mathrm{Al}$ film and electrolyte solution (boundary length between the white and black regions in Figure 6) and (b) projected area of $\mathrm{NbO}_{\mathrm{x}}$ deposits (area of the white color region in Figure 6) estimated from the two-dimensional AFM phase images. 


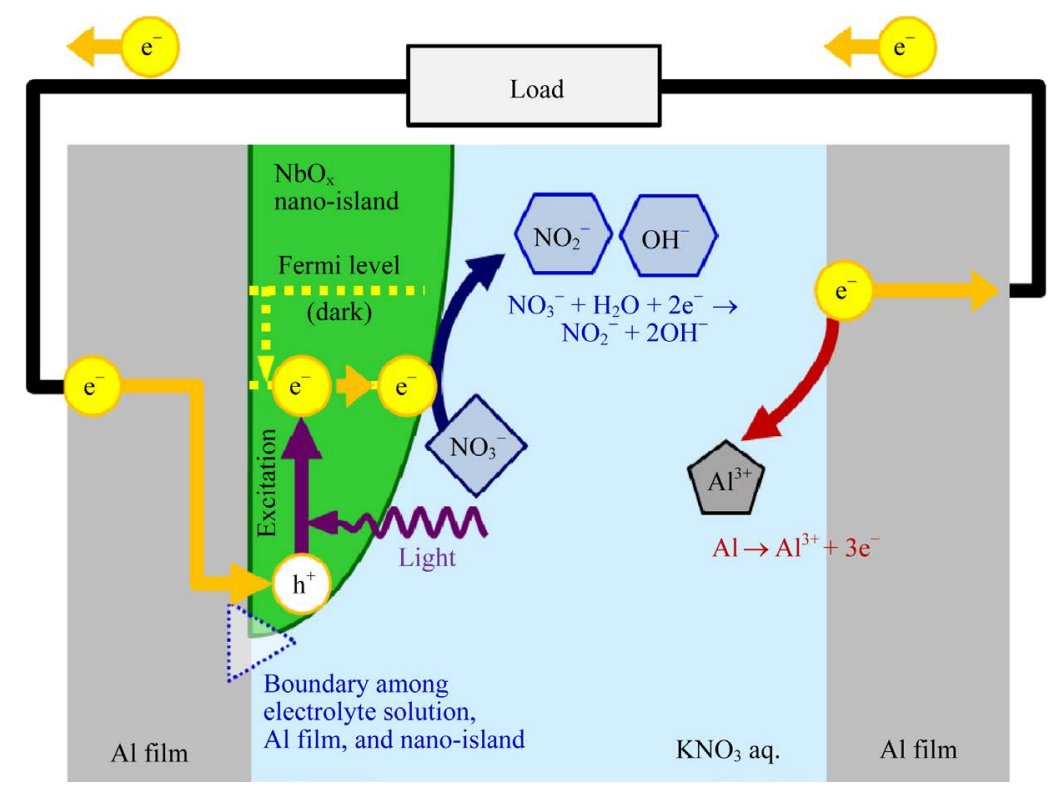

Figure 13. Photoelectrochemical conversion mechanism for the PEC consisting of $\mathrm{NbO}_{\mathrm{x}}$ with nano-island.

surface, because the maxima in $J_{\mathrm{sc}}$ and $P_{\max }$ of nano-island state are larger than those of film state (Figure 5) even though the absorption of irradiated light, that is, the amount of electrons excited into conduction band increases continuously with increasing the $\mathrm{NbO}_{\mathrm{x}}$ deposition time (Figure 9). To improve the power density, it is necessary to increase the boundary length by suppressing the growth of islands parallel to substrate to prevent the contact between the islands despite increasing the number of islands and promoting the growth of islands perpendicular to substrate to achieve the potential bending to improve the carrier mobility.

\subsection{Photoelectrochemical Stability}

In the case of $\mathrm{ZnO}$, various photo corrosion reactions by holes have been proposed.

Han et al. [39]:

$$
\mathrm{ZnO}+2 \mathrm{~h}^{+} \rightarrow \mathrm{Zn}^{2+}+1 / 2 \mathrm{O}_{2}
$$

Rao et al. [40]:

$$
\mathrm{ZnO}+2 \mathrm{H}_{2} \mathrm{O}+2 \mathrm{~h}^{+} \rightarrow \mathrm{Zn}(\mathrm{OH})_{2}+1 / 2 \mathrm{O}_{2}+2 \mathrm{H}^{+}
$$

Fruhwirth et al. [37]:

$$
\mathrm{ZnO}+\mathrm{H}^{+}+\mathrm{h}^{+} \rightarrow \mathrm{Zn}^{2+}+1 / 2 \mathrm{H}_{2} \mathrm{O}_{2}
$$

A corrosion reaction, $\mathrm{Al}+3 \mathrm{~h}^{+} \rightarrow \mathrm{Al}^{3+}$ is also assumed [12]. As above mentioned, the elution of $\mathrm{Zn}$ and $\mathrm{Al}$ from $\mathrm{ZnO} / \mathrm{Al} /$ glass electrode is surely observed, and the elution rate increases during the light irradiation, which is probably due to the photo corrosion reactions concerning holes.

When combined with the results from the AFM observation (Figure 8), it is suggested that $\mathrm{ZnO}$ nano-islands and underlying $\mathrm{Al}$ film are once eluted due to the photo-induced electrochemical corrosions, and the eluted $\mathrm{Zn}^{2+}$ and $\mathrm{Al}^{3+}$ ions are promptly re-precipitated as hydroxides of $\mathrm{Zn}(\mathrm{OH})_{2}$ and $\mathrm{Al}(\mathrm{OH})_{3}$ due to the change in $\mathrm{pH}$ of the electrolyte solution, which is due to the $\mathrm{OH}^{-}$forming and $\mathrm{H}^{+}$consuming reactions given in Equation (1). At the deposition time of $3 \mathrm{~s}$, the precipitates seem to cover all the surfaces after 9th light irradiation (Figure 8(c), Figure 8(f)). It is known that $\mathrm{Zn}(\mathrm{OH})_{2}$ easily dehydrates to change into $\mathrm{ZnO}$ [41], and it is therefore supposed that part of the $\mathrm{Zn}(\mathrm{OH})_{2}$ precipitates change into $\mathrm{ZnO}$. In case of the deposition time of $3 \mathrm{~s}$, the dehydrated $\mathrm{ZnO}$ layer is probably thin but is enough to form potential bending so that electrons and holes can migrate between underlying $\mathrm{Al}$ film and electrolyte solution, resulting in photocurrent generation after repeating photo irradiation (Figure 3). As for the ZnO-based PEC at the deposition time of $17 \mathrm{~s}$, the $\mathrm{Zn}(\mathrm{OH})_{2}$ insulating layer must be 
thicker than the case of $3 \mathrm{~s}$ deposition, and hence photocurrent generation does not happen even though the $\mathrm{ZnO}$ layer is formed on the $\mathrm{Zn}(\mathrm{OH})_{2}$ layer.

According to a potential-pH diagram of $\mathrm{Nb}$ system [38], $\mathrm{Nb}_{2} \mathrm{O}_{5}$ is passive and insoluble in acidic water but is soluble in neutral and alkaline water. According to Equation (1), $\mathrm{pH}$ of electrolyte should be increases with proceeding the photoelectrochemical reactions. Actually, slight increase in $\mathrm{pH} \sim 0.2$ is confirmed after the photocurrent measurements. $\mathrm{Nb}^{5+}$ ions are probably dominant in $\mathrm{NbO}_{\mathrm{x}}$ deposits, and hence $\mathrm{NbO}_{\mathrm{x}}$ deposits should be dissolved in the electrolyte solution. However, $\mathrm{Nb}$ elution is not confirmed by ICP measurement. It is therefore supposed that some protection layer is formed on the surface of $\mathrm{NbO}_{\mathrm{x}}$ deposits. According to the potential-pH diagram, $\mathrm{NbO}_{2}$ and $\mathrm{NbO}$ with lower valence states are passive and insoluble at the entire $\mathrm{pH}$ region. In the present $\mathrm{PECs}$, the $\mathrm{NbO}_{\mathrm{x}} / \mathrm{Al} /$ glass electrodes are negatively polarized, and electrons are concentrated at the electrode surface. It is consequently expected that some of $\mathrm{Nb}^{5+}$ ions are reduced to $4+$ or lower valence state to form a highly passive layer, from which high photo corrosion resistance of $\mathrm{NbO}_{\mathrm{x}} / \mathrm{Al} / \mathrm{glass}$ electrodes should be achieved.

\section{Conclusions}

$\mathrm{ZnO}$ and $\mathrm{NbO}_{\mathrm{x}}$ were deposited on $\mathrm{Al}$-coated glass substrates by an $\mathrm{RF}$ magnetron reactive sputtering, and photoelectrochemical cells, PECs were constructed, in which an $\mathrm{Al} /$ glass was used as a counter electrode and $\mathrm{KNO}_{3}$ solution was chosen as an electrolyte. Electrochemical and photoelectrochemical properties of the PECs were evaluated.

Under the light irradiation from a solar simulator, faint and unstable photocurrent generation was seen in ZnO-based PECs. As for the $\mathrm{NbO}_{\mathrm{x}}$ electrode, however, stable generation was successfully achieved. Very small and few bubbles were generated at both electrodes, and Al elution was found at the counter electrodes. The maximum power output was not proportional to the deposition time of $\mathrm{NbO}_{\mathrm{x}}$, and larger output was obtained when the $\mathrm{NbO}_{\mathrm{x}}$ deposits were not in film, but in nano-island structures.

The photoelectrochemical properties were discussed based on the electrochemical properties. The $\mathrm{ZnO}$ and $\mathrm{NbO}_{\mathrm{x}}$ electrodes had higher electrode potentials than the counter $\mathrm{Al} /$ glass electrode, and electron flows from the counter electrode to the $\mathrm{ZnO}$ or $\mathrm{NbO}_{\mathrm{x}}$ electrodes through the external circuit were commonly confirmed. It was hence supposed that the bubbles generated during the light irradiation were $\mathrm{H}_{2}$ at $\mathrm{ZnO}$ and $\mathrm{NbO}_{\mathrm{x}}$ electrodes and $\mathrm{O}_{2}$ at the counter Al/glass electrode. In the ZnO-based PEC, the elution of $\mathrm{Zn}$ and underlying $\mathrm{Al}$ from the $\mathrm{ZnO}$ electrode was observed in a dark place, and the elution rate increased during the light irradiation. After the light irradiation, precipitates on the $\mathrm{ZnO}$ electrode surface were found in the AFM observations. According to the potential-pH diagrams, it was suggested that the eluted $\mathrm{Zn}^{2+}$ and $\mathrm{Al}^{3+}$ ions were re-precipitated as hydroxides of $\mathrm{Zn}(\mathrm{OH})_{2}$ and $\mathrm{Al}(\mathrm{OH})_{3}$ on the electrode surface, which was due to the change in $\mathrm{pH}$ of the electrolyte solution, being resulted from the $\mathrm{OH}^{-}$generating and $\mathrm{H}^{+}$consuming reactions. During the repetition of photo irradiation, the $\mathrm{Zn}(\mathrm{OH})_{2}$ precipitates changed into thin $\mathrm{ZnO}$ layer, resulting in photocurrent generation. At the $\mathrm{NbO}_{\mathrm{x}}$ electrode, elution was observed neither in a dark place nor during the light irradiation, and quite little change was observed on the $\mathrm{NbO}_{\mathrm{x}}$ electrode surface. From the optical absorption spectra, it was suggested that $\mathrm{Nb}$ ions in $\mathrm{NbO}_{\mathrm{x}}$ deposits were almost present as $\mathrm{Nb}^{5+}$, but they had different electronic state or atomistic structure from $\mathrm{Nb}_{2} \mathrm{O}_{5}$ crystal. Furthermore, it was also suggested that the electronic state and atomistic structure of $\mathrm{NbO}_{\mathrm{x}}$ deposits were unchanged and independent of the deposition time. The maximum power output was correlated not with the deposition time but with the length of the boundary between the $\mathrm{NbO}_{\mathrm{x}}$ nano-islands and the underlying $\mathrm{Al}$ film. Second maximum in power output was also obtained at the longer $\mathrm{NbO}_{\mathrm{x}}$ deposition time, where thin film of $\mathrm{NbO}_{\mathrm{x}}$ deposits was formed. Larger power generation was obtained with the $\mathrm{NbO}_{\mathrm{x}}$ deposits with nanoisland structure.

Based on the experimental findings, the following photoelectrochemical reaction mechanism was suggested: due to the light irradiation, electrons in the $\mathrm{NbO}_{\mathrm{x}}$ deposits were excited into the conduction band, and were used in the reduction of $\mathrm{NO}_{3}^{-}$ions and $\mathrm{H}_{2}$ gas generation. The holes were filled with the electrons supplied from the $\mathrm{Al} /$ glass substrate through the external circuit. In the case of $\mathrm{NbO}_{\mathrm{x}}$ deposits with nano-island structure, it was finally concluded that the photoelectrochemical reactions proceeded in the vicinity of the boundary among the nano-islands, substrate and electrolyte solution, which was a distinctive characteristic derived from the electrodes with nano-island structure. Nano-island was expected as a novel electrode structure in PECs, which might provide higher efficiency in photoelectrochemical conversion by the improvements in geometry designs of nano-islands, choice of materials and deposition conditions. 


\section{References}

[1] Guillevin, N., Heurtault, B.J.B., Geerligs, L.J. and Weeber, A.W. (2011) Development towards 20\% Efficient Si MWT Solar Cells for Low-Cost Industrial Production. Energy Procedia, 8, 9-16. http://dx.doi.org/10.1016/j.egypro.2011.06.094

[2] De Wolf, S., Duerinckx, F., Agostinelli, G. and Beaucarne, G. (2006) Low-Cost Rear Side Floating Junction Solar-Cell Issues on mc-Si. Solar Energy Materials and Solar Cells, 90, 3431-3437. http://dx.doi.org/10.1016/j.solmat.2006.02.035

[3] Huang, J.Y., Lin, C.Y., Shen, C.H., Shieh, J.M. and Dai, B.T. (2012) Low Cost High-Efficiency Amorphous Silicon Solar Cells with Improved Light-Soaking Stability. Solar Energy Materials and Solar Cells, 98, 277-282. http://dx.doi.org/10.1016/j.solmat.2011.11.023

[4] Terakawa, A. (2013) Review of Thin-Film Silicon Deposition Techniques for High-Efficiency Solar Cells Developed at Panasonic/Sanyo. Solar Energy Materials and Solar Cells, 119, 204-208. http://dx.doi.org/10.1016/j.solmat.2013.06.044

[5] Chaudhari, V.A. and Solanki, C.S. (2010) A Novel Two Step Metallization of Ni/Cu for Low Concentrator c-Si Solar Cells. Solar Energy Materials and Solar Cells, 94, 2094-2101. http://dx.doi.org/10.1016/j.solmat.2010.06.032

[6] Chu, L.K., Yen, C.W. and Sayed, M.A.E. (2010) Bacteriorhodopsin-Based Photo-Electrochemical Cell. Biosensors and Bioelectronics, 26, 620-626. http://dx.doi.org/10.1016/j.bios.2010.07.013

[7] Barote, M.A., Kamble, S.S., Deshmukh, L.P. and Masumdar, E.U. (2013) Photo-Electrochemical Performance of $\mathrm{Cd}_{1-x} \mathrm{~Pb}_{x} \mathrm{~S}(0 \leq x \leq 1)$ Thin Films. Ceramics International, 39, 1463-1467. http://dx.doi.org/10.1016/j.ceramint.2012.07.090

[8] Tseng, C.J., Wang, C.H. and Cheng, K.W. (2012) Photoelectrochemical Performance of Gallium-Doped AgInS 2 Photoelectrodes Prepared by Electrodeposition Process. Solar Energy Materials and Solar Cells, 96, 33-42. http://dx.doi.org/10.1016/j.solmat.2011.09.010

[9] Trunk, M., Sobas, A.G., Venkatachalapathy, V., Zhang, T., Galeckas, A. and Kuznetsov, A.Y. (2012) Testing ZnO Based Photoanodes for PEC Applications. Energy Procedia, 22, 101-107. http://dx.doi.org/10.1016/j.egypro.2012.05.221

[10] Jacobsson, T.J., Björkman, C.P., Edoff, M. and Edvinsson, T. (2013) $\mathrm{CuIn}_{\mathrm{x}} \mathrm{Ga}_{1-\mathrm{x}} \mathrm{Se}_{2}$ as an Efficient Photocathode for Solar Hydrogen Generation. International Journal of Hydrogen Energy, 38, 15027-15035. http://dx.doi.org/10.1016/j.ijhydene.2013.09.094

[11] Fujishima, A. and Honda, K. (1972) Electrochemical Photolysis of Water at a Semiconductor Electrode. Nature, 238, 37-38. http://dx.doi.org/10.1038/238037a0

[12] Imajo, T., Okano, H. and Maeda, A. (2008) Photocatalytic Lithography Using Zinc Oxide Nanoislands. Japanese Journal of Applied Physics, 47, 2330. http://dx.doi.org/10.1143/JJAP.47.2330

[13] Prado, A.G.S., Bolzon, L.B., Pedroso, C.P., Moura, A.O. and Costa, L.L. (2008) $\mathrm{Nb}_{2} \mathrm{O}_{5}$ as Efficient and Recyclable Photocatalyst for Indigo Carmine Degradation. Applied Catalysis B: Environmental, 82, 219-224. http://dx.doi.org/10.1016/j.apcatb.2008.01.024

[14] Roza, L., Rahman, M.Y.A., Umar, A.A. and Salleh, M.M. (2015) Direct Growth of Oriented ZnO Nanotubes by Self-Selective Etching at Lower Temperature for Photo-Electrochemical (PEC) Solar Cell Application. Journal of Alloys and Compounds, 618, 153-158. http://dx.doi.org/10.1016/j.jallcom.2014.08.113

[15] Suzuki, S., Teshima, K., Ishizaki, T., Lee, S.H., Yubuta, K., Shishido, T. and Oishi, S. (2011) Unique Three-Dimensional Nano-/Micro-Textured Surfaces Consisting of Highly Crystalline $\mathrm{Nb}_{2} \mathrm{O}_{5}$ Nanotubes. Journal of Crystal Growth, 318, 1095-1100. http://dx.doi.org/10.1016/j.jcrysgro.2010.11.129

[16] Nayeri, F.D., Soleimani, E.A. and Salehi, F. (2013) Synthesis and Characterization of ZnO Nanowires Grown on Different Seed Layers: The Application for Dye-Sensitized Solar Cells. Renewable Energy, 60, 246-255. http://dx.doi.org/10.1016/j.renene.2013.05.006

[17] Lin, Y., Yang, Y.J. and Hsu, C.C. (2011) Synthesis of Niobium Oxide Nanowires Using an Atmospheric Pressure Plasma Jet. Thin Solid Films, 519, 3043-3049. http://dx.doi.org/10.1016/j.tsf.2010.12.024

[18] Ye, N., Qi, J., Qi, Z., Zhang, X., Yang, Y., Liu, J. and Zhang, Y. (2010) Improvement of the Performance of Dye-Sensitized Solar Cells Using Sn-Doped ZnO Nanoparticles. Journal of Power Sources, 195, 5806-5809. http://dx.doi.org/10.1016/j.jpowsour.2010.03.036

[19] Méndez, S.M., Henríquez, Y., Domínguez, O., D’Ornelas, L. and Krentzien, H. (2006) Catalytic Properties of Silica Supported Titanium, Vanadium and Niobium Oxide Nanoparticles towards the Oxidation of Saturated and Unsaturated Hydrocarbons. Journal of Molecular Catalysis A: Chemical, 252, 226-234.

http://dx.doi.org/10.1016/j.molcata.2006.02.041 
[20] Kang, Z., Gu, Y., Yan, X., Bai, Z., Liu, Y., Liu, S., Zhang, X., Zhang, Z., Zhang, X. and Zhang, Y. (2015) Enhanced Photoelectrochemical Property of ZnO Nanorods Array Synthesized on Reduced Graphene Oxide for Self-Powered Biosensing Application. Biosensors and Bioelectronics, 64, 499-504. http://dx.doi.org/10.1016/j.bios.2014.09.055

[21] Wen, H., Liu, Z., Wang, J., Yang, Q., Li, Y. and Yu, J. (2011) Facile Synthesis of $\mathrm{Nb}_{2} \mathrm{O}_{5}$ Nanorod Array Films and Their Electrochemical Properties. Applied Surface Science, 257, 10084-10088. http://dx.doi.org/10.1016/j.apsusc.2011.07.001

[22] Kou, H., Zhang, X., Du, Y., Ye, W., Lin, S. and Wang, C. (2011) Electrochemical Synthesis of ZnO Nanoflowers and Nanosheets on Porous Si as Photoelectric Materials. Applied Surface Science, 257, 4643-4649. http://dx.doi.org/10.1016/j.apsusc.2010.12.108

[23] Choi, B., Myung, N. and Rajeshwar, K. (2007) Double Template Electrosynthesis of ZnO Nanodot Array. Electrochemistry Communications, 9, 1592-1595. http://dx.doi.org/10.1016/j.elecom.2007.02.025

[24] Qi, S., Zuo, R., Liu, Y. and Wang, Y. (2013) Synthesis and Photocatalytic Activity of Electrospun Niobium Oxide Nanofibers. Materials Research Bulletin, 48, 1213-1217. http://dx.doi.org/10.1016/j.materresbull.2012.11.074

[25] Bonakdarpour, A., Tucker, R.T., Fleischauer, M.D., Beckers, N.A., Brett, M.J. and Wilkinson, D.P. (2012) Nanopillar Niobium Oxides as Support Structures for Oxygen Reduction Electrocatalysts. Electrochimica Acta, 85, 492-500. http://dx.doi.org/10.1016/j.electacta.2012.08.005

[26] Hayashi, Y., Arita, M., Koga, K. and Masuda, M. (1995) Photo-Electrochemical Properties of Hydrogen in Anodically Oxidized Niobium. Journal of Alloys and Compounds, 231, 702-705. http://dx.doi.org/10.1016/0925-8388(95)01756-9

[27] Sugisaki, N., Niizuma, K. and Ikawa, H. (2010) Photocatalytic Effect of Niobium Oxide Film by RF Magnetron Sputtering Method. College of Industrial Technology, Nihon University Lecture Meeting.

[28] Lide, D.R. (2001) CRC Handbook of Chemistry and Physics. 82nd Edition, CRC Press, Boca Raton.

[29] Asano, T., Kubo, T. and Nishikitani, Y. (2005) Short-Circuit Current Density Behavior of Dye-Sensitized Solar Cells. Japanese Journal of Applied Physics, 44, 6776-6780. http://dx.doi.org/10.1143/JJAP.44.6776

[30] Kim, J.H. and Ahn, K.S. (2010) Tri-Branched Tri-Anchoring Organic Dye for Visible Light-Responsive Dye-Sensitized Photoelectrochemical Water-Splitting Cells. Japanese Journal of Applied Physics, 49, Article ID: 060219. http://dx.doi.org/10.1143/JJAP.49.060219

[31] Onodera, M., Nagumo, R., Miura, R., Suzuki, A., Tsuboi, H., Hatakeyama, N., Endou, A., Takada, H., Kubo, M. and Miyamoto, A. (2011) Multiscale Simulation of Dye-Sensitized Solar Cells Considering Schottky Barrier Effect at Photoelectrode. Japanese Journal of Applied Physics, 50, Article ID: 04DP06. http://dx.doi.org/10.1143/JJAP.50.04DP06

[32] Pourbaix, M. (1966) Atlas of Electrochemical Equilibria in Aqueous Solutions. Pergamon Press, Oxford.

[33] Yagi, S., Kondo, Y., Satake, Y., Ashida, A. and Fujimura, N. (2012) Local pH Control by Electrolysis for ZnO Epitaxial Deposition on a Pt Cathode. Electrochimica Acta, 62, 348-353. http://dx.doi.org/10.1016/j.electacta.2011.12.059

[34] Han, Y., Chen, Z., Tong, L., Yang, L., Shen, J., Wang, B., Liu, Y., Liu, Y. and Chen, Q. (2013) Reduction of $\mathrm{N}$-Nitrosodimethylamine with Zero-Valent Zinc. Water Research, 47, 216-224. http://dx.doi.org/10.1016/j.watres.2012.09.043

[35] Wranglén, G. (1985) An Introduction to Corrosion and Protection of Metals. Chapman \& Hall, London. http://dx.doi.org/10.1007/978-94-009-4850-1

[36] Kojima, Y. (2011) Electrochemical Analysis for Corrosion Behavior of Aluminum, Keikinzoku. Journal of Japan Institute of Light Metals, 61, 167. (In Japanese).

[37] Fruhwirth, O., Herzog, G.W. and Poulios, J. (1985) Dark Dissolution and Photodissolution of ZnO. Surface Technology, 24, 293-300. http://dx.doi.org/10.1016/0376-4583(85)90079-2

[38] Asselin, E., Ahmed, T.M. and Alfantazi, A. (2007) Corrosion of Niobium in Sulphuric and Hydrochloric Acid Solutions at 75 and $95{ }^{\circ} \mathrm{C}$. Corrosion Science, 49, 694-710. http://dx.doi.org/10.1016/j.corsci.2006.05.028

[39] Han, J., Qiu, W. and Gao, W. (2010) Potential Dissolution and Photo-Dissolution of ZnO Thin Films. Journal of Hazardous Materials, 178, 115-122. http://dx.doi.org/10.1016/j.jhazmat.2010.01.050

[40] Rao, M.V., Rajeshwar, K., Pal Verneker, V.R. and Du Bow, J. (1980) Photosynthetic Production of $\mathrm{H}_{2}$ and $\mathrm{H}_{2} \mathrm{O}_{2}$ on Semiconducting Oxide Grains in Aqueous Solutions. The Journal of Physical Chemistry, 84, 1987-1991. http://dx.doi.org/10.1021/j100452a023

[41] Izaki, M. and Omi, T. (1996) Electrolyte Optimization for Cathodic Growth of Zinc Oxide Films. Journal of The Electrochemical Society, 143, L53-L55. http://dx.doi.org/10.1149/1.1836529 